\title{
Evaluation of tropospheric and stratospheric ozone trends over Western Europe from ground-based FTIR network observations
}

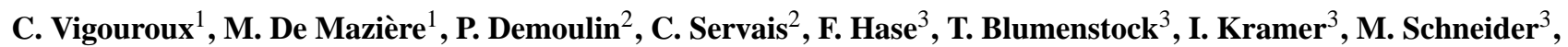 \\ J. Mellqvist ${ }^{4}$, A. Strandberg ${ }^{4}$, V. Velazco ${ }^{5}$, J. Notholt ${ }^{5}$, R. Sussmann ${ }^{6}$, W. Stremme ${ }^{6}$, A. Rockmann ${ }^{6}$, T. Gardiner ${ }^{7}$, \\ M. Coleman ${ }^{7}$, and P. Woods ${ }^{7}$ \\ ${ }^{1}$ Belgian Institute for Space Aeronomy (BIRA-IASB), Brussels, Belgium \\ ${ }^{2}$ Institut d'Astrophysique et de Géophysique, University of Liège (ULg), Liège, Belgium \\ ${ }^{3}$ Institute for Meteorology and Climate Research (IMK-ASF), Forschungszentrum Karlsruhe and University of Karlsruhe, \\ Karlsruhe, Germany \\ ${ }^{4}$ Chalmers University of Technology, Göteborg, Sweden \\ ${ }^{5}$ Institute of Environmental Physics, University of Bremen, Bremen, Germany \\ ${ }^{6}$ Institute for Meteorology and Climate Research (IMK-IFU), Forschungszentrum Karlsruhe, Garmisch-Partenkirchen, \\ Germany \\ ${ }^{7}$ National Physical Laboratory, Teddington, UK
}

Received: 3 January 2008 - Published in Atmos. Chem. Phys. Discuss.: 7 March 2008

Revised: 17 October 2008 - Accepted: 17 October 2008 - Published: 1 December 2008

\begin{abstract}
Within the European project UFTIR (Time series of Upper Free Troposphere observations from an European ground-based FTIR network), six ground-based stations in Western Europe, from $79^{\circ} \mathrm{N}$ to $28^{\circ} \mathrm{N}$, all equipped with Fourier Transform infrared (FTIR) instruments and part of the Network for the Detection of Atmospheric Composition Change (NDACC), have joined their efforts to evaluate the trends of several direct and indirect greenhouse gases over the period 1995-2004. The retrievals of $\mathrm{CO}, \mathrm{CH}_{4}$, $\mathrm{C}_{2} \mathrm{H}_{6}, \mathrm{~N}_{2} \mathrm{O}, \mathrm{CHClF}_{2}$, and $\mathrm{O}_{3}$ have been optimized. Using the optimal estimation method, some vertical information can be obtained in addition to total column amounts. A bootstrap resampling method has been implemented to determine annual partial and total column trends for the target gases. The present work focuses on the ozone results. The retrieved time series of partial and total ozone columns are validated with ground-based correlative data (Brewer, Dobson, UV-Vis, ozonesondes, and Lidar). The observed total column ozone trends are in agreement with previous studies: 1) no total column ozone trend is seen at the lowest latitude station Izaña $\left(28^{\circ} \mathrm{N}\right) ; 2$ ) slightly positive total column
\end{abstract}

trends are seen at the two mid-latitude stations Zugspitze and Jungfraujoch $\left(47^{\circ} \mathrm{N}\right)$, only one of them being significant; 3 ) the highest latitude stations Harestua $\left(60^{\circ} \mathrm{N}\right)$, Kiruna $\left(68^{\circ} \mathrm{N}\right)$ and Ny-Ålesund $\left(79^{\circ} \mathrm{N}\right)$ show significant positive total column trends. Following the vertical information contained in the ozone FTIR retrievals, we provide partial columns trends for the layers: ground- $10 \mathrm{~km}, 10-18 \mathrm{~km}, 18-27 \mathrm{~km}$, and $27-42 \mathrm{~km}$, which helps to distinguish the contributions from dynamical and chemical changes on the total column ozone trends. We obtain no statistically significant trends in the ground $-10 \mathrm{~km}$ layer for five out of the six ground-based stations. We find significant positive trends for the lowermost stratosphere at the two mid-latitude stations, and at $\mathrm{Ny}-$ Ålesund. We find smaller, but significant trends for the 18$27 \mathrm{~km}$ layer at Kiruna, Harestua, Jungfraujoch, and Izaña. The results for the upper layer are quite contrasted: we find significant positive trends at Kiruna, Harestua, and Jungfraujoch, and significant negative trends at Zugspitze and Izaña. These ozone partial columns trends are discussed and compared with previous studies.
Correspondence to: C. Vigouroux

(corinne.vigouroux@ aeronomie.be) 


\section{Introduction}

The increase of radiatively active gases in the atmosphere and their impact on climate changes are among the most important environmental problems of today. Therefore it is important to monitor their evolution to understand the present climate and predict future climate changes. Ground-based Fourier transform infrared (g-b FTIR) measurements allow the determination of the atmospheric abundances of many constituents. Long-term and regular observations, necessary to determine the variability and long-term trends of the atmospheric species, are made at many stations within the Network for the Detection of Atmospheric Composition Change $\left(\mathrm{NDACC}^{1}\right)$. Within the framework of the European project UFTIR $^{2}$ (Time series of Upper Free Troposphere observations from a European ground-based FTIR network), presented in De Mazière et al. (2005), six g-b FTIR stations have joined their efforts to evaluate the trends over the period 1995-2004 of several direct and indirect greenhouse gases. All the stations are situated in Western Europe, covering a large latitudinal range from $28^{\circ} \mathrm{N}$ to $79^{\circ} \mathrm{N}$. Common strategies for the retrievals of $\mathrm{CO}, \mathrm{CH}_{4}, \mathrm{C}_{2} \mathrm{H}_{6}, \mathrm{~N}_{2} \mathrm{O}$, $\mathrm{CHClF}_{2}$ (HCFC-22), and $\mathrm{O}_{3}$ have been established to optimize the vertical information content of the retrieved profiles. Therefore, the FTIR retrieval products include distinct tropospheric and stratospheric abundances, in addition to standard total column amounts. A bootstrap resampling method has been applied to the time series of these abundances in order to obtain tropospheric, stratospheric and total column trends. This method is described in Gardiner et al. (2008).

Stratospheric ozone is produced by photolysis of molecular oxygen and removed by dynamical and chemical processes. The ozone global mean total column for the period 1997-2001 was about 3\% below the pre-1980 average value (WMO, 2003). This ozone depletion depends on the latitude: no significant trend was observed in the tropics, while the Northern and Southern Hemisphere ( $\mathrm{NH}$ and $\mathrm{SH}$ ) midlatitude $\left(35^{\circ}-60^{\circ}\right)$ ozone total columns were $3 \%$ and $6 \%$ below their pre-1980 values, respectively. The decline of global total column ozone is attributed mainly to the reactive chlorine and bromine coming from anthropogenic emissions. The implementation of the 1987 Montreal Protocol and its Amendments and Adjustments has led to a reduction of the emissions of ozone-depleting substances (ODSs). In 2005, the abundances of these anthropogenic gases in the troposphere had decreased by $8-9 \%$ from the peak value observed in the 1992-1994 period (WMO, 2006). The Equivalent Effective Stratospheric Chlorine (EESC) was defined (Daniel et al., 1995) to relate the ODSs abundances in the troposphere to the inorganic chlorine and bromine abundances in the stratosphere, and hence to ozone depletion. Since it takes a few years for the ODSs to reach the stratosphere (about

\footnotetext{
${ }^{1}$ http://www.ndacc.org

${ }^{2}$ http://www.nilu.no/uftir
}

three years at mid-latitude and lower stratosphere, and three to five more years for polar latitude and upper stratosphere), the EESC is decreasing since the late 1990s (WMO, 2006), and a turnaround of the negative stratospheric ozone trend followed by a recovery of stratospheric ozone to the pre- 1980 values is expected as a response to the Montreal Protocol. Indeed, the global mean total ozone in the 2002-2005 period is similar to the 1998-2001 values, indicating that ozone is no longer decreasing (WMO, 2006). The fact that the observed turnaround is an evidence for the beginning of the ozone "recovery", which has been defined (WMO, 2006) to be "due to changing EESC", is still under debate. Indeed, several authors have detected a turnaround in the last decades negative trend of mid-latitude total ozone (Hadjinicolaou et al., 2005; Reinsel et al., 2005; Stolarski and Frith, 2006), where the individual contributions of the dynamical and chemical changes vary according to the studies. The evaluation of the vertical distribution of the stratospheric ozone trends is very helpful to separate dynamical and chemical contributions, since they differ according to the altitude (Yang et al., 2006): the lowermost stratosphere is more influenced by dynamical changes, whereas the upper stratosphere is more sensitive to EESC changes. In the present paper, we demonstrate that time series of g-b FTIR measurements are very suitable for studying the vertical distribution of stratospheric ozone trends since they can provide independent ozone partial columns amounts in three different altitude layers in the stratosphere.

As a greenhouse and surface air pollutant gas, and as a precursor of the $\mathrm{OH}$ oxidant, tropospheric ozone is therefore the subject of many studies (for a review, see IPCC, 2001). Tropospheric ozone is produced by photochemical oxidation of carbon monoxide, methane and nonmethane volatile organic compounds (NMVOCs) in the presence of nitrogen oxide radicals $\mathrm{NO}_{\mathrm{x}}\left(\mathrm{NO}+\mathrm{NO}_{2}\right)$. The other main source of tropospheric ozone is transport from the stratosphere, the socalled STE process (for stratosphere-troposphere exchange). Its main sinks are photochemical and chemical reactions and dry deposition. Depending on the geographical location, season, and altitude (surface or free troposphere), the sign and magnitude of the tropospheric trends can be very different according to the possible causes of the observed ozone changes (Oltmans et al., 2006). In Europe, an increase of tropospheric ozone occurred at mid-latitude from pre-industrial times to the 1980s due to the increase of anthropogenic emissions of ozone precursors (such as $\mathrm{NO}_{\mathrm{x}}$ ). In the last two decades, ozonesonde measurements in Western Europe show a levelling off or a slight decrease of tropospheric ozone depending on the station (Oltmans et al., 2006). Indeed, while emissions are increasing in parts of Asia, the European and North American emissions have been reduced since the late 1980s (Jonson et al., 2006). However, MOZAIC (Measurement of Ozone and Water Vapor by Airbus In-service Aircraft) aircraft measurements show increased tropospheric ozone in the 1995-2001 period in Paris and Frankfurt (Zbinden et al., 
2006). The situation is different at high latitudes, which are far from polluted areas and therefore more influenced by horizontal and vertical (STE) transport (Tarasick et al., 2005; Kivi et al., 2007). For the period 1996-2003, ozonesonde observations in the Arctic indicate positive trends of tropospheric ozone (Kivi et al., 2007). Since the observed trends seem to vary depending on the studies, even in close locations at NH mid-latitudes, our UFTIR data set from six FTIR stations in Europe provides an important contribution to the study of ozone trends in the troposphere.

In Sect. 2, we describe the $\mathrm{O}_{3}$ retrieval strategies that have been adopted by the six ground-based FTIR stations. We show that the vertical information content that can be obtained from FTIR solar absorption measurements by using the optimal estimation method (OEM) of Rodgers (2000), allows us to separate the atmosphere into four independent layers: ground- $\sim 10 \mathrm{~km}, \sim 10-18 \mathrm{~km}, \sim 18-27 \mathrm{~km}$, and $\sim 27-$ $42 \mathrm{~km}$. In Sect. 3, the ozone total and partial column time series obtained at each station are presented and validated by comparison with correlative ground-based data (Brewer, Dobson, UV-Vis, ozonesondes, and Lidar). Section 4 discusses the ozone total and partial column trends for the period 1995-2004, as obtained with the bootstrap resampling method of Gardiner et al. (2008).

\section{FTIR observations}

\subsection{Instruments}

Table 1 identifies the six ground-based FTIR stations, located in Western Europe, that are contributing to the UFTIR network. These stations have been making regular solar absorption measurements for many years and the derived time series of total column abundances of many atmospheric species are available in the NDACC database. The measurements are performed over a wide spectral range (around 600$4500 \mathrm{~cm}^{-1}$ ), using the high-resolution spectrometers Bruker $120 \mathrm{M}$ for Izaña and Harestua, and Bruker $120 \mathrm{HR}$ for the other stations. The spectrometers can achieve a spectral resolution of 0.0035 and $0.002 \mathrm{~cm}^{-1}$, respectively.

\subsection{FTIR retrieval strategy}

The aim of the UFTIR project has been to retrieve, in addition to standard total column amounts, vertical profile information, and thus to provide time series for different altitude ranges. The derivation of low vertical resolution profiles is possible thanks to the pressure dependence of the absorption line shapes. The "inversion" process is an ill-posed problem that is solved using the Optimal Estimation Method (OEM) developed by Rodgers (2000). Two different algorithms have been used in the present work, PROFFIT9 (Hase, 2000) at Kiruna and Izaña, and SFIT2 (Pougatchev et al., 1995; Rinsland et al., 1998) at the other stations. It has been demonstrated in Hase et al. (2004) that the profiles and total column
Table 1. Location and altitude (in km above sea level) of the six g-b FTIR stations that are contributing to the UFTIR network.

\begin{tabular}{lrrr}
\hline Station & Latitude & Longitude & Altitude $(\mathrm{km})$ \\
\hline Ny-Ålesund & $79^{\circ} \mathrm{N}$ & $12^{\circ} \mathrm{E}$ & 0.02 \\
Kiruna & $68^{\circ} \mathrm{N}$ & $20^{\circ} \mathrm{E}$ & 0.42 \\
Harestua & $60^{\circ} \mathrm{N}$ & $11^{\circ} \mathrm{E}$ & 0.60 \\
Zugspitze & $47^{\circ} \mathrm{N}$ & $11^{\circ} \mathrm{E}$ & 2.96 \\
Jungfraujoch & $47^{\circ} \mathrm{N}$ & $8^{\circ} \mathrm{E}$ & 3.58 \\
Izaña & $28^{\circ} \mathrm{N}$ & $16^{\circ} \mathrm{W}$ & 2.37 \\
\hline
\end{tabular}

amounts retrieved from these two different algorithms under identical conditions are in excellent agreement; in particular, total column amounts of $\mathrm{O}_{3}$ agree to within $0.5 \%$.

In both codes, the retrieved vertical profiles are obtained by fitting one or more narrow spectral intervals (microwindows). The OEM needs the a priori vertical volume mixing ratio (VMR) profiles of the target gas and interfering species and the a priori covariance matrix associated with the target gas profile. The retrieved state vector contains the retrieved VMR of the target gas defined in discrete layers or at discrete altitude levels in the atmosphere, as well as all other fitted parameters, e.g., the retrieved scaling factors for the interfering species' column amounts, and fitted values for some model parameters. The latter can include the baseline slope of the spectrum and instrumental line shape parameters such as an effective apodization parameter.

The vertical information content of the retrieved profiles depends strongly on the choice of microwindows and a priori information, which are part of the retrieval strategy. One of the UFTIR objectives has been to optimize the retrieval strategy in order to maximize the vertical information regarding the target gas, in the troposphere and in the stratosphere. Each individual station has its own specificities (different altitudes, different ozone amounts and variabilities, ...), thus it is almost impossible that a completely identical set of parameters leads to an optimal strategy at all the sites simultaneously. Only the parameters that are essential to avoid systematic biases between the various stations results have been homogenized: these are the retrieval micro-windows and the spectroscopic database. Each partner optimized the other retrieval parameters, such as the a priori information, for his site.

The vertical information content of the retrieved target gas profile can be quantified by the number of degrees of freedom for signal (DOFS), which is the trace of the so-called averaging kernel matrix A, defined in Rodgers (2000) by:

$\boldsymbol{x}_{r}=\boldsymbol{x}_{a}+\mathbf{A}\left(\boldsymbol{x}-\boldsymbol{x}_{a}\right)+$ error terms,

where $\boldsymbol{x}_{r}$ and $\boldsymbol{x}_{a}$ are the retrieved and a priori state vectors, respectively, and $\boldsymbol{x}$ is the true state vector. All vectors are 
Table 2. Summary of the retrieval parameters used at the six UFTIR stations. All microwindows (MW) are given in $\mathrm{cm}^{-1}$.

\begin{tabular}{|c|c|c|c|c|c|}
\hline & Ny-Ålesund & Kiruna / Izaña & Harestua & Zugspitze & Jungfraujoch \\
\hline Retrieval code & SFIT2 v 3.81 & PROFFIT9 & SFIT2 v 3.81 & SFIT2 v 3.81 & SFIT2 v 3.81 \\
\hline Spectroscopy & HITRAN 2004 & HITRAN 2004 & HITRAN 2004 & HITRAN 2004 & HITRAN 2004 \\
\hline $\mathrm{p}, \mathrm{T}$ profiles & $\begin{array}{l}\text { Daily sondes } \\
\text { Upper altitude: } \\
\text { standard atmosphere }\end{array}$ & NCEP & $\begin{array}{l}\text { Daily sondes } \\
\text { Upper altitude: } \\
\text { NCEP }\end{array}$ & $\begin{array}{l}\text { Daily sondes } \\
\text { Upper altitude: } \\
\text { standard atmosphere }\end{array}$ & NCEP \\
\hline $\begin{array}{l}\mathrm{MW} \\
\text { for } \mathrm{O}_{3} \text { profile } \\
\text { retrievals }\end{array}$ & $1000-1005$ & $\begin{array}{l}1000-1005 \\
782.56-782.86 \\
788.85-789.37 \\
993.3-993.8\end{array}$ & $1000-1005$ & $1000.57-1003.2$ & $1000-1005$ \\
\hline $\begin{array}{l}\text { Retrieved } \\
\text { Interfering } \\
\text { species }\end{array}$ & $\mathrm{H}_{2} \mathrm{O}$ & $\begin{array}{l}\mathrm{H}_{2} \mathrm{O} \\
\mathrm{CO}_{2}, \mathrm{C}_{2} \mathrm{H}_{4} \\
\mathrm{O} 668, \mathrm{O} 686\end{array}$ & $\begin{array}{l}\mathrm{H}_{2} \mathrm{O} \\
\mathrm{CO}_{2}, \mathrm{C}_{2} \mathrm{H}_{4}\end{array}$ & $\begin{array}{l}\mathrm{H}_{2} \mathrm{O} \text { profiles } \\
\text { simultaneously } \\
\text { retrieved in: } \\
1110.8-1112.2\end{array}$ & $\begin{array}{l}\mathrm{H}_{2} \mathrm{O} \\
\mathrm{CO}_{2}, \mathrm{C}_{2} \mathrm{H}_{4} \\
\mathrm{O} 668, \mathrm{O} 686\end{array}$ \\
\hline $\begin{array}{l}\text { A priori } \mathrm{H}_{2} \mathrm{O} \\
\text { profiles } \\
\text { and } \mathrm{MW}\end{array}$ & Daily sondes & $\begin{array}{l}\text { Daily from } \\
\text { independent } \\
\text { retrievals in: } \\
1110.0-1113.0 \\
1117.3-1117.9 \\
1120.1-1122.0\end{array}$ & $\begin{array}{l}\text { Monthly a priori } \\
\text { from sondes } \\
\text { at Blindern } \\
(1998-2002)\end{array}$ & $\begin{array}{l}\text { Yearly } 1976 \text { US } \\
\text { standard atmosphere }\end{array}$ & $\begin{array}{l}\text { Daily from } \\
\text { independent } \\
\text { retrievals in: } \\
1110.0-1113.0 \\
1117.3-1117.9 \\
1120.1-1122.0\end{array}$ \\
\hline $\begin{array}{l}\text { A priori } \mathrm{O}_{3} \\
\text { profiles }\end{array}$ & $\begin{array}{l}\text { Yearly from sondes } \\
(1994-2004) \text { and } \\
\text { HALOE climatology } \\
\text { at this latitude }\end{array}$ & $\begin{array}{l}\text { Summer Remedios } \\
\text { climatology: } \\
\text { polar (Kiruna) } \\
\text { and midlatitudes } \\
\text { (Izaña) }\end{array}$ & $\begin{array}{l}\text { Monthly } \\
\text { from sondes } \\
(1995-2000) \text { and } \\
\text { HALOE climatology } \\
\text { at this latitude }\end{array}$ & $\begin{array}{l}\text { Yearly } 1976 \text { US } \\
\text { standard atmosphere }\end{array}$ & $\begin{array}{l}\text { Yearly from sondes } \\
\text { at Payerne and } \\
\text { microwave at Bern } \\
(1995-1999)\end{array}$ \\
\hline $\mathbf{S}_{a}$ & $\begin{array}{l}\text { Constant with } \\
\text { altitude }(10 \%) \text {. } \\
\text { Gaussian correlation } \\
\text { HWHM : } 8 \mathrm{~km}\end{array}$ & $\begin{array}{l}\text { Constant with } \\
\text { altitude }(10 \%) \text {. } \\
\text { No correlation }\end{array}$ & $\begin{array}{l}\text { Constant with } \\
\text { altitude }(10 \%) \text {. } \\
\text { Gaussian correlation } \\
\text { HWHM : } 5 \mathrm{~km}\end{array}$ & $\begin{array}{l}\text { From Oslo CTM2 } \\
\text { smoothed } \\
\text { Gaussian correlation } \\
\text { HWHM : } 4 \mathrm{~km}\end{array}$ & $\begin{array}{l}\text { Constant with } \\
\text { altitude }(10 \%) \text {. } \\
\text { Gaussian correlation } \\
\text { HWHM : } 4 \mathrm{~km}\end{array}$ \\
\hline $\begin{array}{l}\text { SNR for } \\
\text { retrievals }\end{array}$ & 100 & $100-150$ & 140 & 217 & 200 \\
\hline $\begin{array}{l}\text { Instrument } \\
\text { Line Shape }\end{array}$ & $\begin{array}{l}\text { ILS fixed } \\
\text { ideal }\end{array}$ & $\begin{array}{l}\text { ILS fixed: } \\
\text { - ideal (Kiruna) } \\
\text { - } 40 \text { parameters } \\
\text { from LINEFIT } \\
\text { (Izaña) }\end{array}$ & $\begin{array}{l}\text { ILS fixed: } \\
\text { - modulation from } \\
\text { LINEFIT, } 1 \text { parameter } \\
\text { with linear decrease } \\
\text { - no phase error }\end{array}$ & $\begin{array}{l}\text { - Polynomial fit } \\
\text { (second order) } \\
\text { of modulation } \\
\text { - no phase error }\end{array}$ & $\begin{array}{l}\text { - Polynomial fit } \\
\text { (second order) } \\
\text { of modulation } \\
\text { - no phase error }\end{array}$ \\
\hline
\end{tabular}

limited to the part representing the target gas profile to facilitate the discussion in the following subsections.

\subsubsection{Choice of microwindows and spectroscopic databases}

The UFTIR strategy for $\mathrm{O}_{3}$ retrievals includes the use of the 1000-1005 $\mathrm{cm}^{-1}$ microwindow: it has been demonstrated
(Barret et al., 2002) that it gives a DOFS for target gas between 4 and 5, i.e., at least one more than the 1002.6$1003.2 \mathrm{~cm}^{-1}$ microwindow previously used in Pougatchev et al. (1995), and that it is less sensitive to possible correlations between fitted instrument line shape parameters and retrieved VMR profiles. The spectral region around $3051 \mathrm{~cm}^{-1}$ recently used at Poker Flat (Kagawa et al., 2007) also gives about one DOFS less. The choice of the spectral region in the 
first two studies was guided by the presence of a high number of $\mathrm{O}_{3}$ lines with different intensities which gives information both in the stratosphere and the troposphere. On the other hand, these $\mathrm{O}_{3}$ lines are very sensitive to errors in the temperature profiles. Indeed, the temperature profile is a fixed parameter in the retrieval process: daily pressure/temperature profiles have been taken either from daily sondes when available, or from the National Centers for Environmental Prediction (NCEP), as summarized in Table 2. Schneider et al. (2005) exploited $\mathrm{O}_{3}$ signatures around $785 \mathrm{~cm}^{-1}$ that are less temperature sensitive but provide less information in the troposphere. Very recently, Schneider and Hase (2008) proposed a simultaneous retrieval of $\mathrm{O}_{3}$ and temperature in the $1000-1005 \mathrm{~cm}^{-1}$ microwindow. This approach significantly reduces the impact of errors in the temperature profiles on the retrieved $\mathrm{O}_{3}$ profiles (Schneider and Hase, 2008; Schneider et al., 2008) . Another disadvantage of the $1000-1005 \mathrm{~cm}^{-1}$ microwindow is the presence of interfering water vapour lines. Therefore, the interfering water vapour profiles have been dealt with carefully, as explained in the next section. At Zugspitze however, the window was shortened to avoid water vapour lines. At Kiruna and Izaña, three microwindows have been added to have better sensitivity for high solar zenith angle measurements. The choice of microwindows and the corresponding interfering species are listed in Table 2, for each station. The absorptions of all interfering species that appear in the micro-windows are included in the simulated spectra. Thus, the absorption lines due to $\mathrm{CO}_{2}, \mathrm{C}_{2} \mathrm{H}_{4}$, and $\mathrm{O}_{3}$ isotopes are also calculated at the stations where they are not retrieved. The only difference is that at these stations, the profiles of these molecules are fixed to their a priori profiles. The reason for that is that the absorption of the interfering gas can be so small that a simultaneous retrieval of the interfering species' profile or column does not improve the target gas retrieval nor the spectral residual.

All stations have used HITRAN 2004 spectroscopic line parameters (Rothman et al., 2005). It has been noticed that this choice minimizes or avoids some oscillations that appear when using the HITRAN 2000 database including official updates through 2001 (Rothman et al., 2003).

\subsubsection{Choice of a priori information}

Generally, the a priori profiles of the interfering species are taken from climatology. In the retrieval procedure, these profiles are scaled together with the inversion of the target gas profile. But, considering the importance of water vapour lines in our ozone microwindow and the high variability of water vapour in the atmosphere, special care was taken for this molecule, as follows. At the Zugspitze station, the $\mathrm{H}_{2} \mathrm{O}$ profile was retrieved simultaneously with the $\mathrm{O}_{3}$ one, using an additional microwindow optimized for $\mathrm{H}_{2} \mathrm{O}$ retrievals. At Kiruna, Izaña and Jungfraujoch, daily $\mathrm{H}_{2} \mathrm{O}$ a priori profiles were determined first, in three microwindows selected for that purpose and listed in Table 2, and then scaled in the $\mathrm{O}_{3}$ retrieval process. At $\mathrm{Ny}$-Ålesund, some daily sondes are available and thus used as a priori profiles up to around $30 \mathrm{~km}$. They are extrapolated to higher altitudes by a yearly standard climatology. At Harestua, the individual prior retrievals of water vapour, which are more difficult for low altitude sites, failed. As no daily sondes were available as at $\mathrm{Ny}$-Ålesund, the traditional approach of scaling a climatological profile was adopted. The $\mathrm{O}_{3}$ a priori profiles are taken from different climatology depending on the location of the stations. Table 2 summarizes, for each station, the sources of the $\mathrm{O}_{3}$ and $\mathrm{H}_{2} \mathrm{O}$ a priori profiles.

Another element of a priori information that has a strong influence on the retrieved profiles and on the DOFS is the a priori covariance matrix $\mathbf{S}_{a}$. Ideally, this matrix should express the natural variability of the target gas, and thus should be as realistic as possible and evaluated from climatological data (Rodgers, 2000). The diagonal elements of $\mathbf{S}_{a}$ represent the variability of the target gas VMR at a given altitude, and the non-diagonal elements represent the correlation between the VMR at different altitudes. The SFIT2 version 3.81 used during the UFTIR project only accepts a Gaussian-shaped correlation between layers of which the half width at half maximum (HWHM) has to be specified ${ }^{3}$. One option to determine the diagonal elements of the a priori covariance matrix is to use daily profiles from a 3-D Chemistry-Transport Model (CTM), e.g., the Oslo CTM2 model (Isaksen et al., 2005). This option has been taken at the Zugspitze station: it leads to a variability around $14 \%$ in the lower troposphere, rising to about $57 \%$ at the tropopause. The $\mathbf{S}_{a}$ matrix adopted in the Zugspitze retrievals has kept this overall shape, but slightly smoothed to a maximum variability of about $50 \%$ at the tropopause. Because CTM2 is essentially a tropospheric model, the diagonal elements of $\mathbf{S}_{a}$ decreased smoothly from $8 \%$ at about $27 \mathrm{~km}$ to zero at $70 \mathrm{~km}$, thereby underestimating the real variability. This explains why smaller DOFS are obtained at Zugspitze for the altitude range above $27 \mathrm{~km}$, as will be seen in the next section.

Experience shows that a realistic $\mathbf{S}_{a}$ matrix that imposes only a weak constraint on the a priori profile can lead to oscillations in the retrieved profile. To avoid this problem, it was suggested to adopt an a priori covariance matrix with $10 \%$ variability on the diagonal, at all altitudes. At the Jungfraujoch station, the latter approach was compared with the one adopted at Zugspitze. The retrieval results are equivalent for total and middle to high stratospheric columns. But in the troposphere, it appeared that the agreement with correlative ozonesonde data was better using the more constrained $\mathbf{S}_{a}$ matrix (10\%). Therefore, the latter option was adopted at almost all stations (see Table 2). One should notice that, even if all stations (except Zugspitze) are using a $\mathbf{S}_{a}$ matrix with diagonal elements representing $10 \%$ of variability, this does not mean that they are applying exactly the same constraint

\footnotetext{
${ }^{3}$ A new version v 3.9 is now available that allows full, and therefore more realistic, $\mathbf{S}_{a}$ matrix to be employed.
} 
Table 3. Characterization of the $\mathrm{O}_{3}$ retrieved profiles at each station: the typical degrees of freedom for signal (DOFS), and Sensitivity Range (SR) of the ground-based FTIR retrievals (Gd: ground; TC: total column; PC: partial column).

\begin{tabular}{|c|c|c|c|c|}
\hline Station & $\begin{array}{l}\text { TC } \\
\text { DOFS }\end{array}$ & $\begin{array}{l}\mathrm{SR} \\
(\mathrm{km})\end{array}$ & $\begin{array}{l}\text { Limits } \\
\text { of PC }(\mathrm{km})\end{array}$ & $\begin{array}{l}\text { PC } \\
\text { DOFS }\end{array}$ \\
\hline Ny-Ålesund & 4.6 & $\mathrm{Gd}-51$ & $\begin{array}{l}\text { Gd-9.0 } \\
9.0-17.0 \\
17.0-27.0 \\
27.0-41.0\end{array}$ & $\begin{array}{l}1.0 \\
1.0 \\
1.1 \\
1.0\end{array}$ \\
\hline Kiruna & 5.0 & $\mathrm{Gd}-42$ & $\begin{array}{l}\text { Gd-9.8 } \\
9.8-18.3 \\
18.3-27.7 \\
27.7-41.6\end{array}$ & $\begin{array}{l}1.3 \\
1.1 \\
1.4 \\
1.0\end{array}$ \\
\hline Harestua & 5.6 & $\mathrm{Gd}-40$ & $\begin{array}{l}\text { Gd-10.6 } \\
10.6-17.6 \\
17.6-27.6 \\
27.6-39.8\end{array}$ & $\begin{array}{l}1.5 \\
1.2 \\
1.6 \\
1.1\end{array}$ \\
\hline Zugspitze & 4.3 & Gd-37 & $\begin{array}{l}\text { Gd-11.0 } \\
11.0-17.9 \\
17.9-27.9 \\
27.9-41.9\end{array}$ & $\begin{array}{l}1.1 \\
1.3 \\
1.4 \\
0.5\end{array}$ \\
\hline Jungfraujoch & 4.6 & $\mathrm{Gd}-44$ & $\begin{array}{l}\text { Gd-10.6 } \\
10.6-17.8 \\
17.8-27.4 \\
27.4-42.4\end{array}$ & $\begin{array}{l}1.0 \\
1.0 \\
1.3 \\
1.2\end{array}$ \\
\hline Izaña & 4.8 & $\mathrm{Gd}-45$ & $\begin{array}{l}\text { Gd-10.7 } \\
10.7-18.3 \\
18.3-27.7 \\
27.7-41.6\end{array}$ & $\begin{array}{l}1.0 \\
1.0 \\
1.5 \\
1.1\end{array}$ \\
\hline
\end{tabular}

to the retrievals. As one can see in Table 2, the Gaussian correlation length has been chosen differently at each station. It corresponds to typical climatological data, except for $\mathrm{Ny}$ Ålesund and Kiruna. Also the effective signal to noise ratio (SNR) in the retrievals is different from one station to another. This effective SNR is smaller than the value derived from the inherent noise in the spectra, since the residuals in a spectral fit are not only coming from pure measurement noise but also from uncertainties in the model parameters. The effective SNR is used as a regularization parameter. It is the ratio of both adjustable parameters $\mathbf{S}_{a}$ and SNR that defines the respective weights of a priori and measurement information in the retrieval, i. e., the averaging kernel matrix $\mathbf{A}$. This is evident from the following equation (Rodgers, 2000):

$\mathbf{A}=\left(\mathbf{K}^{T} \mathbf{S}_{\epsilon}^{-1} \mathbf{K}+\mathbf{S}_{a}^{-1}\right)^{-1} \mathbf{K}^{T} \mathbf{S}_{\epsilon}^{-1} \mathbf{K}$,

where $\mathbf{S}_{\epsilon}$ is the measurement error covariance matrix and $\mathbf{K}$ is the weighting function matrix that links the measurement vector $\boldsymbol{y}$ to the state vector $\boldsymbol{x}: \boldsymbol{y}=\mathbf{K} \boldsymbol{x}+\boldsymbol{\epsilon}$, with $\boldsymbol{\epsilon}$ representing the measurement error. In our retrievals, we assume $\mathbf{S}_{\epsilon}$ to be diagonal, in which case the diagonal elements are the inverse square of the effective SNR.

\subsubsection{Instrument line shape}

The VMR profiles of target gases are retrieved using the shape of their absorption lines. The observed absorption line shapes also depend on the instrument line shape (ILS) which is therefore needed in the forward models of the retrieval codes. Among the UFTIR stations, three different parameterisations of the ILS have been used. At Kiruna, NyÅlesund, Harestua, and Izaña, the ILS has been retrieved independently from $\mathrm{HBr}$ or $\mathrm{N}_{2} \mathrm{O}$ absorption measurements in a low-pressure gas cell with the LINEFIT code, as described in Hase et al. (1999). In this approach, the loss of modulation efficiency and the phase error can be described 1) by 40 parameters (20 for each) at equidistant optical path differences (OPDs); 2) or simply by two parameters assuming a linear decline of the modulation efficiency with OPD, and a constant phase error. For the two former stations, the LINEFIT results were close to, and thus have been approximated by, the ideal ILS: there is no loss of modulation efficiency versus OPD and no phase error. At Izaña, the ILS was not ideal and the 40 parameters obtained from LINEFIT have been used to describe the ILS. At Harestua, the second option of parameters from LINEFIT was used and the phase error, which can lead to asymmetrical ILS but which was close to zero, was neglected. At Zugspitze and Jungfraujoch, it also has been taken into account that the ILS may not be ideal: the ILS distortions have been approximated by an empirical apodization function (that represents only symmetrical distortions). In the case of an ideal instrument, the apodization function would be constant and equal to 1 . In case of a non ideal ILS, the parameters of the empirical function are retrieved together with the VMR profiles, using the ideal ILS as the a priori value. A polynomial fit of order 2 has been used. The phase error, close to zero, has been neglected.

\subsection{Vertical information in FTIR retrievals}

As mentioned previously, the vertical information contained in the FTIR retrievals can be characterized by the averaging kernel matrix A. This matrix depends on measurement and retrieval parameters including the solar zenith angle, the spectral resolution and signal to noise ratio, the choice of spectral microwindows, and the a priori covariance matrix $\mathbf{S}_{a}$. The rows of $\mathbf{A}$ are the so-called averaging kernels and they represent the sensitivity of the retrieved profile to the real profile. Their full width at half maximum (FWHM) is a measure of the vertical resolution of the retrieval at a given altitude. We give in Fig. 1 the typical averaging kernels for the $\mathrm{O}_{3}$ retrievals at the Jungfraujoch station. According to their FWHM, the vertical resolution is about $8 \mathrm{~km}$ for $\mathrm{O}_{3}$. On top of the kernels plotted in Fig. 1, we have added the 


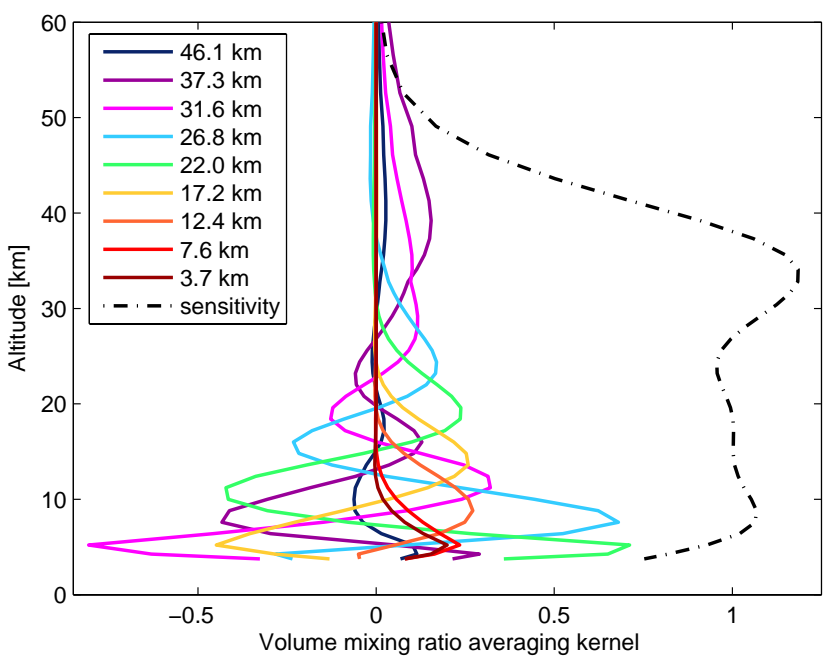

Fig. 1. Characterization of the $\mathrm{O}_{3}$ retrieval at Jungfraujoch. Full lines: volume mixing ratio averaging kernels (ppmv/ppmv) for the altitudes listed in the legend. Dotted line: Sensitivity of the retrieval as a function of altitude.

so-called "sensitivity" of the retrievals to the measurements. This sensitivity at altitude $k$ is calculated as the sum of the elements of the corresponding averaging kernel, $\sum_{i} A_{k i}$. It indicates, at each altitude, the fraction of the retrieval that comes from the measurement rather than from the a priori information. A value close to zero at a certain altitude indicates that the retrieved profile at that altitude is nearly independent of the real profile and is therefore approaching the a priori profile. Figure 1 shows that the ground-based FTIR measurements of $\mathrm{O}_{3}$ at Jungfraujoch have a sensitivity larger than 0.5 from the ground to about $44 \mathrm{~km}$ altitude. This means that the retrieved profile information above $44 \mathrm{~km}$ comes for less than $50 \%$ from the measurement, or, in other words, that the a priori information influences the retrieval by more than $50 \%$.

Depending on the measurements and the retrieval parameters used at the various stations, the altitude range over which the retrieved profiles are fairly sensitive to the measurements, as well as the DOFS will be different. Table 3 gives, for each station, the vertical ranges where the sensitivity is larger than 0.5 (called Sensitivity Ranges, SR, in the table). The typical DOFS obtained at each station over the whole altitude range (TC DOFS) are also added in Table 3: they are about 4.7. They correspond to a measurement at a typical solar zenith angle. The standard deviation $(1 \sigma)$ of DOFS for all measurements at different solar zenith angles is typically 0.2 . Therefore hereinafter, we will not discuss profiles but rather partial column amounts in four independent layers. The layer limits have been chosen such that the DOFS is at least 1.0 in each associated partial column. The thus defined layers are independent on the basis of the resolution of the averaging kernels, as can be seen in Fig. 2, where the partial column averaging kernels of the four layers in the case of Jungfrau-

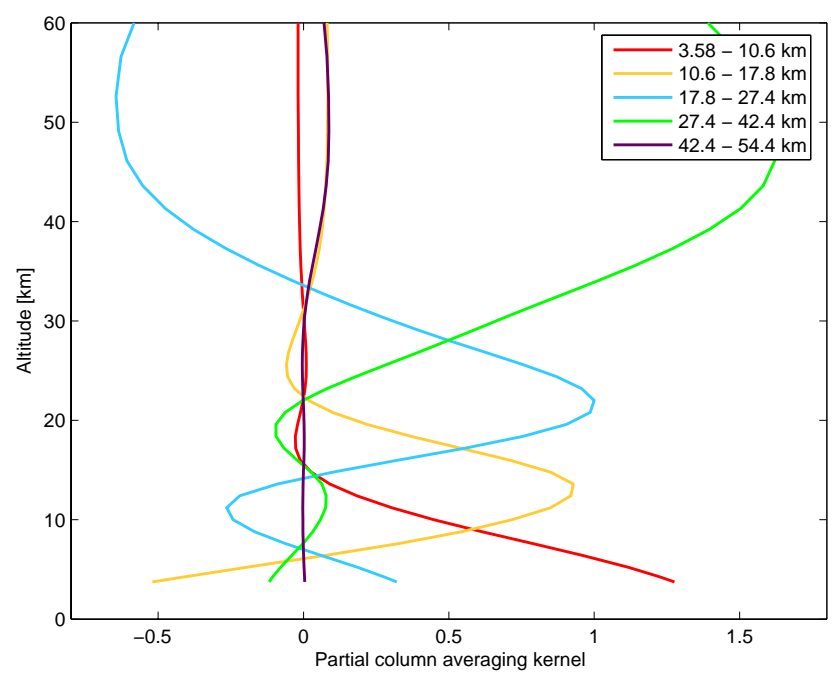

Fig. 2. Partial column averaging kernels $\left(\mathrm{mol} . \mathrm{cm}^{-2} / \mathrm{mol} . \mathrm{cm}^{-2}\right.$ ) for $\mathrm{O}_{3}$ at Jungfraujoch.

joch are given. Indeed, we see that the four layers are independent, i.e. that their averaging kernels are resolved at their FWHM, and that the averaging kernels peak at the right altitude, i.e., at the middle of the chosen layer limits. In Table 3, we give the altitude ranges of the layers for each station, and the typical DOFS contained in the corresponding partial columns. We see from Table 3 that the layering divide approximately the atmosphere in one tropospheric layer, and three stratospheric ones. For the lowest layers, the upper limits do not correspond to the real tropopause heights, but are slightly below their mean values, derived from the NCEP database, that are 10.1, 10.6, 11.0, 11.8, 11.8, and $14.9 \mathrm{~km}$ for Ny-Ålesund, Kiruna, Harestua, Zugspitze, Jungfraujoch, and Izaña, respectively. The standard deviations from these means are about $1.1 \mathrm{~km}$, except for Izaña where it is $1.6 \mathrm{~km}$. For the latter station, the $10.7-18.3 \mathrm{~km}$ layer will be a mixture of troposphere and stratosphere, while it will be quasi purely stratosphere for the other stations. Nevertheless, we did not find major changes in the trends at Izaña when choosing a higher upper limit for the lowest layer such as $13.7 \mathrm{~km}$, probably because the trends of the two lowest layers at this station are similar as will be seen in Sect. 4. Thus we have chosen to keep similar limits for all the stations.

\subsection{FTIR random uncertainties}

One can distinguish three main sources of random uncertainties for the FTIR retrieved profiles: the measurement error due to the measurement noise, the model parameters error, and the smoothing error expressing the low vertical resolution of the FTIR retrievals. 


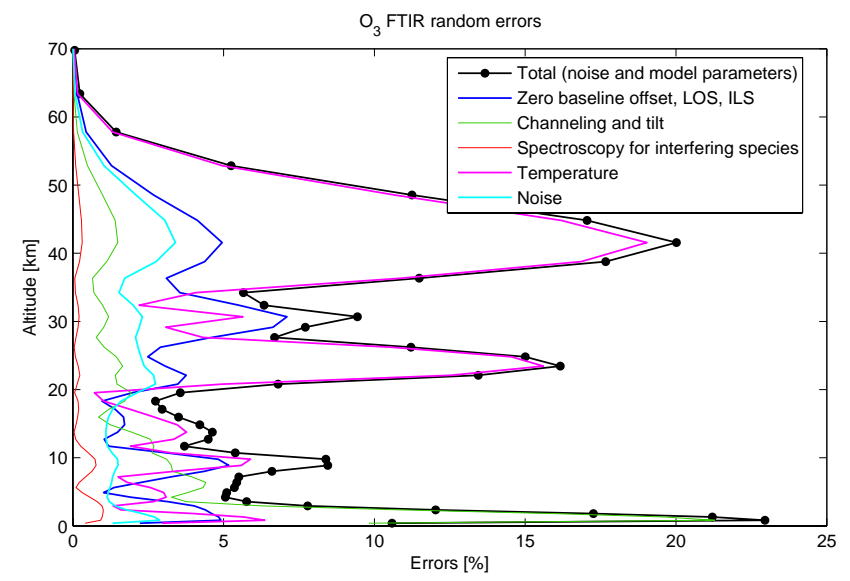

Fig. 3. Ground-based FTIR random errors (in \%). for the $\mathrm{O}_{3}$ retrievals at Kiruna. LOS: line-of-sight; ILS: instrument line shape

\subsubsection{Noise and model parameters errors}

Figure 3 shows the square-root of the variances ("error bars") of the spectral noise and individual model parameters contributions to the random error covariance matrix of the $\mathrm{O}_{3}$ retrievals, as well as the combined random error. The structure in the error profiles shape reflects the effect of the propagation of the different errors in the retrieval process. It appears clearly that the dominant sources of random uncertainties are the temperature profile uncertainties and the baseline error, except in the troposphere where the channelling and tilt error dominates. As the instruments and the retrieval settings are very similar for all UFTIR stations, a unique noise and model parameters error budget has been evaluated for the typical case of a measurement at Kiruna with a solar zenith angle of $70^{\circ}$.

From the error covariance matrix $\mathbf{S}_{x}$ associated with a given error source, we can calculate the associated error $\triangle \mathrm{PC}$ on the partial columns defined in Table 3 . This calculation is made according to:

$$
\Delta \mathrm{PC}=\boldsymbol{g}^{T} \mathbf{S}_{x} \boldsymbol{g}
$$

in which $g$ is the operator that transforms the volume mixing ratio profile in the appropriate partial column amount. The elements of $\boldsymbol{g}$ are equal to zero for the altitudes outside of the concerned partial column boundaries. We give in Table 4 the combined noise and parameters errors, for each of the four partial columns in the case of the Jungfraujoch layers. The total column error can be evaluated in the same manner, $g$ covering the whole altitude range of the retrieved state vector, namely from the ground to about $100 \mathrm{~km}$. The typical FTIR combined (noise and model parameters) random error on the $\mathrm{O}_{3}$ total column is $4.2 \%$.
Table 4. Combined noise and model parameters errors, smoothing errors, total (combined and smoothing) random errors, for partial and total columns at Jungfraujoch.

\begin{tabular}{lcccc}
\hline $\begin{array}{l}\text { Limits } \\
(\mathrm{km})\end{array}$ & $\begin{array}{c}\text { Noise-model } \\
\text { error }(\%)\end{array}$ & $\begin{array}{c}\text { Smoothing } \\
\text { error }(\%)\end{array}$ & $\begin{array}{c}\text { Total random } \\
\text { error }(\%)\end{array}$ & $\begin{array}{c}\text { Natural } \\
\text { variability }(\%)\end{array}$ \\
\hline $3.6-10.6$ & 3.7 & 9.0 & 9.7 & 30 \\
$10.6-17.8$ & 2.9 & 5.9 & 6.6 & 41 \\
$17.8-27.4$ & 8.1 & 2.7 & 8.5 & 11 \\
$27.4-42.4$ & 4.9 & 3.3 & 5.9 & 10 \\
$3.6-100$ & 4.2 & 0.4 & 4.2 & 12 \\
\hline
\end{tabular}

\subsubsection{Smoothing error}

The smoothing error $\mathbf{S}_{S}$ associated with the low vertical resolution retrieved profiles is (Rodgers, 2000):

$\mathbf{S}_{s}=(\mathbf{A}-\mathbf{I}) \mathbf{S}_{\mathrm{var}}(\mathbf{A}-\mathbf{I})^{T}$,

with $\mathbf{S}_{\mathrm{var}}$ the covariance matrix associated with the true natural variability of the $\mathrm{O}_{3}$ profiles. This $\mathbf{S}_{\mathrm{var}}$ matrix is different from station to station. As an example, at the Jungfraujoch station, $\mathbf{S}_{\mathrm{var}}$ has been evaluated using sonde measurements at Payerne and $\mathrm{HALOE}^{4}$ observations around the location of the station, for the altitudes below and above $22 \mathrm{~km}$ respectively. From the sonde measurements, the $\mathrm{O}_{3}$ natural variability reaches a maximum of $77 \%$ at the tropopause, whereas we have seen in Sect. 2.2.2 that the Oslo CTM2 model predicts 57\%. This indicates that the Oslo CTM2 model probably underestimates the $\mathrm{O}_{3}$ natural variability.

Table 4 gives the smoothing error for the four partial columns at Jungfraujoch. We see from Table 4, that the smoothing error is the major source of error on the $\mathrm{O}_{3}$ profiles below $18 \mathrm{~km}$, where the $\mathrm{O}_{3}$ variability is largest. However, when comparing the g-b FTIR data with correlative data that have a much higher vertical resolution, the correlative profiles are smoothed with the FTIR averaging kernels. This procedure makes the impact of the smoothing error on the error budget associated with the comparisons negligible (Rodgers and Connor, 2003).

Furthermore, the contribution of the smoothing error to the total column random error is minor: using Eq. (3), we obtain less than $0.5 \%$ for smoothing error, which is negligible compared to the total column random error coming from the other contributions mentioned in the previous section $(4.2 \%)$.

\subsubsection{Total error}

The total random error for the total column has been evaluated in this work to be $4.2 \%$. The difference with the value of $3.3 \%$ reported by Barret et al. $(2002,2003)$, who use the

\footnotetext{
${ }^{4}$ The HALogen Occultation Experiment on board UARS, the Upper Atmosphere Research Satellite.
} 
Table 5. Statistical means (M) and standard deviations (STD) of the relative differences between the $\mathrm{O}_{3}$ total columns from the FTIR and correlative (CORR, being Dobson, UV-Vis or Brewer) measurements, in percentage. The numbers of comparisons $\mathrm{N}$ involved in the different statistics are given between parentheses. The standard error on the mean $(\mathrm{SEM}=3 \mathrm{STD} / \sqrt{\mathrm{N}})$ and the random error $\Delta \mathrm{DIFF} / \mathrm{mean}(\mathrm{CORR})$ on the comparisons are also included (in [\%]).

\begin{tabular}{|c|c|c|c|c|c|c|}
\hline FTIR station & CORR station & $\mathrm{M}[\%]$ & STD [\%] & $\mathrm{N}$ & SEM [\%] & Random error [\%] \\
\hline \multirow{3}{*}{$\begin{array}{l}\text { Ny-Ålesund } \\
79^{\circ} \mathrm{N}, 20 \mathrm{~m} \text { a.s.1 } \\
1995-2004\end{array}$} & $\begin{array}{l}\text { UV-Vis at Ny-Ålesund }{ }^{\text {a }} \\
\text { 1995-2001 }\end{array}$ & +12.0 & 8.5 & (136) & 2.2 & 4.9 \\
\hline & $\begin{array}{l}\text { UV-Vis at Ny-Ålesund }{ }^{b} \\
\text { 2002-2004 }\end{array}$ & +12.1 & 6.7 & $(15)$ & 5.2 & 4.7 \\
\hline & $\begin{array}{l}\text { Dobson at Ny-Ålesund }{ }^{c} \\
\text { 1995-1997 }\end{array}$ & +0.7 & 3.1 & (7) & 3.5 & 4.2 \\
\hline $\begin{array}{l}\text { Kiruna } \\
68^{\circ} \mathrm{N}, 420 \mathrm{~m} \text { a.s.1 } \\
1996-2004\end{array}$ & $\begin{array}{l}\text { Brewer at Sodankylä c } \\
1996-2004(241 \mathrm{~km}, 179 \text { m a.s.l. })\end{array}$ & +2.7 & 6.9 & $(431)$ & 1.0 & 4.5 \\
\hline $\begin{array}{l}\text { Harestua } \\
60^{\circ} \mathrm{N}, 596 \mathrm{~m} \text { a.s.1 }\end{array}$ & $\begin{array}{l}\text { UV-Vis at Harestua } \\
\text { 1998-2005 }\end{array}$ & +9.4 & 6.6 & (374) & 1.0 & 4.6 \\
\hline 1995-2005 & $\begin{array}{l}\text { Dobson at Oslo }{ }^{\mathrm{c}} \\
1995-1998(35 \mathrm{~km}, 90 \mathrm{~m} \text { a.s.1.) }\end{array}$ & +8.6 & 5.0 & $(88)$ & 1.6 & 4.3 \\
\hline $\begin{array}{l}\text { Zugspitze } \\
47^{\circ} \mathrm{N}, 2964 \mathrm{~m} \text { a.s.1 } \\
1995-2004\end{array}$ & $\begin{array}{l}\text { Dobson at Hohenpeissenberg }{ }^{a} \\
\text { 1995-2004 (43 km, } 975 \text { m a.s.1.) }\end{array}$ & +0.4 & 3.6 & (341) & 0.6 & 4.3 \\
\hline $\begin{array}{l}\text { Jungfraujoch } \\
46.5^{\circ} \mathrm{N}, 3580 \mathrm{~m} \text { a.s.1 } \\
1995-2004\end{array}$ & $\begin{array}{l}\text { UV-Vis at Jungfraujoch }{ }^{\text {a }} \\
\text { 1995-2004 }\end{array}$ & +1.5 & 3.9 & $(627)$ & 0.5 & 4.5 \\
\hline $\begin{array}{l}\text { Izaña } \\
28^{\circ} \mathrm{N}, 2367 \mathrm{~m} \text { a.s.1 } \\
1999-2004\end{array}$ & $\begin{array}{l}\text { Brewer at Izanã a } \\
\text { 1999-2004 }\end{array}$ & +2.9 & 3.8 & (446) & 0.5 & 4.4 \\
\hline
\end{tabular}

a Source: NDACC; ${ }^{\text {b }}$ Source: CALVAL; ${ }^{\mathrm{c}}$ Source: WOUDC.

same micro-window, can be explained partly by the fact that Barret et al. (2002, 2003) have not taken into account baseline error, and that they have assumed a temperature uncertainty of $1.5 \mathrm{~K}$, whereas we have adopted a $2 \mathrm{~K}$ uncertainty. It is obvious in Fig. 3 that the temperature error is the dominant error contribution in the stratosphere. Therefore the recent approach of Schneider and Hase (2008) and Schneider et al. (2008), which widely eliminates this error, allows the improvement of future FTIR $\mathrm{O}_{3}$ retrievals.

The dominant systematic error on total columns is the $\mathrm{O}_{3}$ line intensity uncertainty (Barret et al., 2003; Schneider et al., 2005; Kagawa et al., 2007; Schneider and Hase, 2008). The $\mathrm{O}_{3}$ air broadening coefficient uncertainty is an important source of uncertainty when considering the retrieved profiles and partial columns. For example, the total column amounts obtained using HITRAN 2004, as in the present work, are about $3.5-4 \%$ higher than the ones obtained using the HITRAN 2000 database version (not shown in this paper). This is in agreement with the differences in the $\mathrm{O}_{3}$ line intensi- ties in the $10 \mu \mathrm{m}$ region between HITRAN 2000 (Rothman et al., 2003) and HITRAN 2004 (Rothman et al., 2005) that includes $\mathrm{O}_{3}$ line parameters following the work of Flaud et al. (2003).

\section{Time series of $\mathrm{O}_{3}$ g-b FTIR products and validation}

In the frame of the UFTIR project, the six g-b FTIR stations have reprocessed their time series of $\mathrm{O}_{3}$. The periods covered by the time series are given in Table 5 . Because we consider only solar absorption measurements, the time series at $\mathrm{Ny}$ Ålesund and Kiruna cover only the March-September and January-November periods, respectively. 

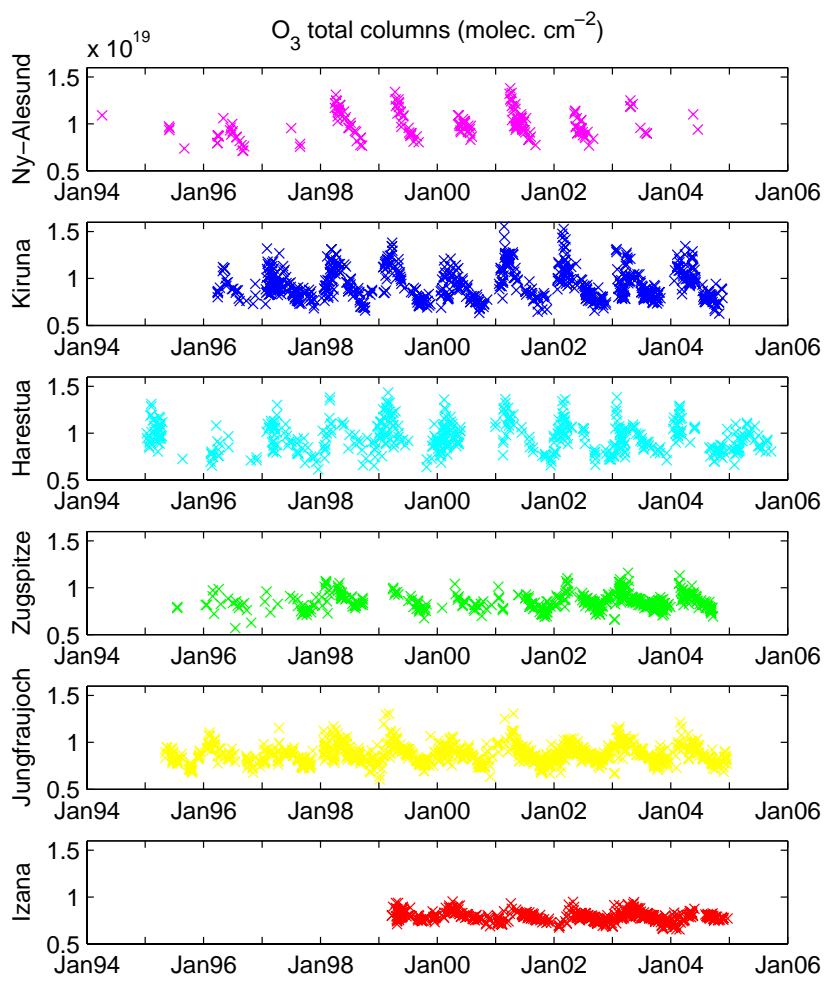

Fig. 4. Time series of $\mathrm{O}_{3}$ total columns at each station.

\section{$3.1 \mathrm{O}_{3}$ total columns}

\subsubsection{FTIR total column time series}

Figure 4 displays the time series of $\mathrm{O}_{3}$ total columns at each g-b FTIR station. We clearly see the well-known seasonal variation of ozone having a maximum in spring (Brasseur and Solomon, 1984). The seasonal variation is isolated in Fig. 5 which shows the monthly mean total columns over the periods of measurements. Also well-known (Brasseur and Solomon, 1984) is the lower amount of ozone at lower latitudes in all seasons (Izaña), and the higher amplitude seasonal variation at higher latitudes. The larger total column amounts at higher latitudes are mainly due to higher ozone concentrations below $20 \mathrm{~km}$, where transport, and particularly the downward poleward (Brewer-Dobson) circulation, plays an important role (Brasseur and Solomon, 1984).

\subsubsection{Validation with ground-based correlative data}

Comparisons have been made with ground-based correlative data (CORR). The daily means of FTIR data have been compared with the daily means of correlative data on the same day. Whenever possible, we have selected correlative data taken at the same location. For Kiruna and Zugspitze, only one year of local correlative measurements was available, thus in order to validate the time series, we have made comparison with data from Sodankylä and

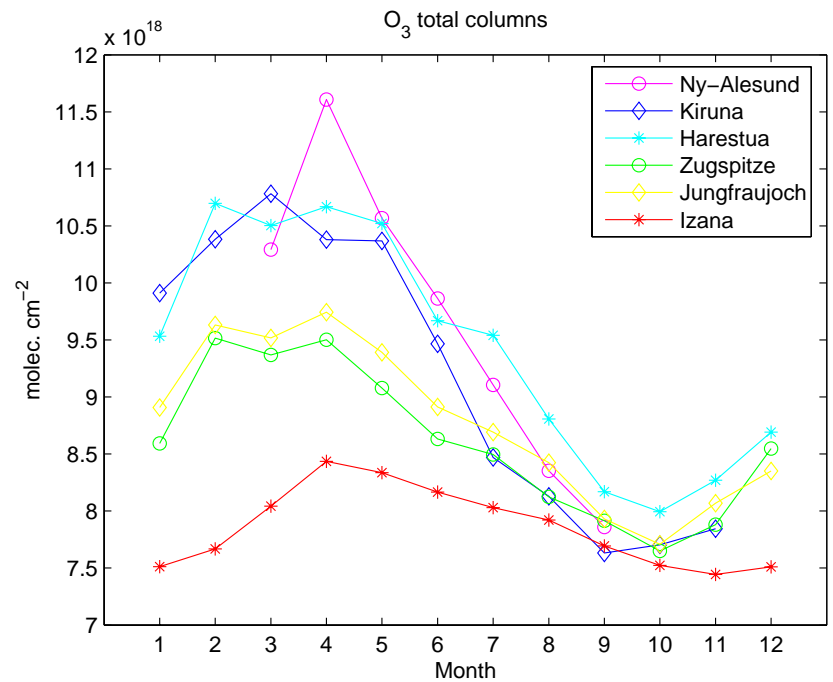

Fig. 5. Monthly mean of $\mathrm{O}_{3}$ total columns at each station.

Hohenpeissenberg located $241 \mathrm{~km}$ and $43 \mathrm{~km}$ from Kiruna and Zugspitze, respectively. The correlative data are from Dobson, Brewer or UV-Vis observations, and have been retrieved from the NDACC database, the Envisat Calibration/Validation Database (CALVAL, http://nadir.nilu.no/ calval/), or the World Ozone and Ultraviolet Radiation Data Centre (WOUDC, http://www.woudc.org/).

The results of the comparisons are given in Table 5. They are expressed in terms of the statistical means of the relative differences $\mathrm{M}$, with $\mathrm{M}=$ mean(FTIR-CORR)/mean(CORR), and the statistical $1 \sigma$ standard deviations, STD, in percent, with STD=std(FTIR-CORR)/mean(CORR). The bias $M$ is statistically significant if it is larger than the standard error on the mean defined as $\mathrm{SEM}=3 * \mathrm{STD} / \sqrt{\mathrm{N}}$, with $\mathrm{N}$ the number of comparisons in the statistics. The random error on the absolute difference FTIR-CORR is simply: $\triangle \mathrm{DIFF}=\sqrt{\Delta \mathrm{FTIR}^{2}+\Delta \mathrm{CORR}^{2}}$, with $\triangle \mathrm{FTIR}$ and $\triangle \mathrm{CORR}$ the absolute random errors on the FTIR and correlative measurements, respectively. The standard deviation of the differences (STD) can be compared to the random error on the difference in percent, $\triangle \mathrm{DIFF} / \mathrm{mean}(\mathrm{CORR})$. As seen in Sect. 2.4.1, the FTIR random error on total column has been estimated to be about $4.2 \%$. The correlative random error is usually much smaller than the FTIR one. The UV-Vis random error is between about $0.2 \%$ (for Harestua) and $1.6 \%$ (for Jungfraujoch), and the Brewer and Dobson random errors are typically $1 \%$. Thus, as can be seen in Table 5, the correlative random error contribution to the combined random errors is small.

First, considering the biases, we can notice from Table 5 that a significant positive bias is present at all the stations except for the Dobson comparisons at Zugspitze and $\mathrm{Ny}$ Ålesund. This significant bias is below 3\% for Jungfraujoch, Izaña, and Kiruna. We have seen in Sect. 2.4.2 that the systematic error due to the $\mathrm{O}_{3}$ line intensity parameter 


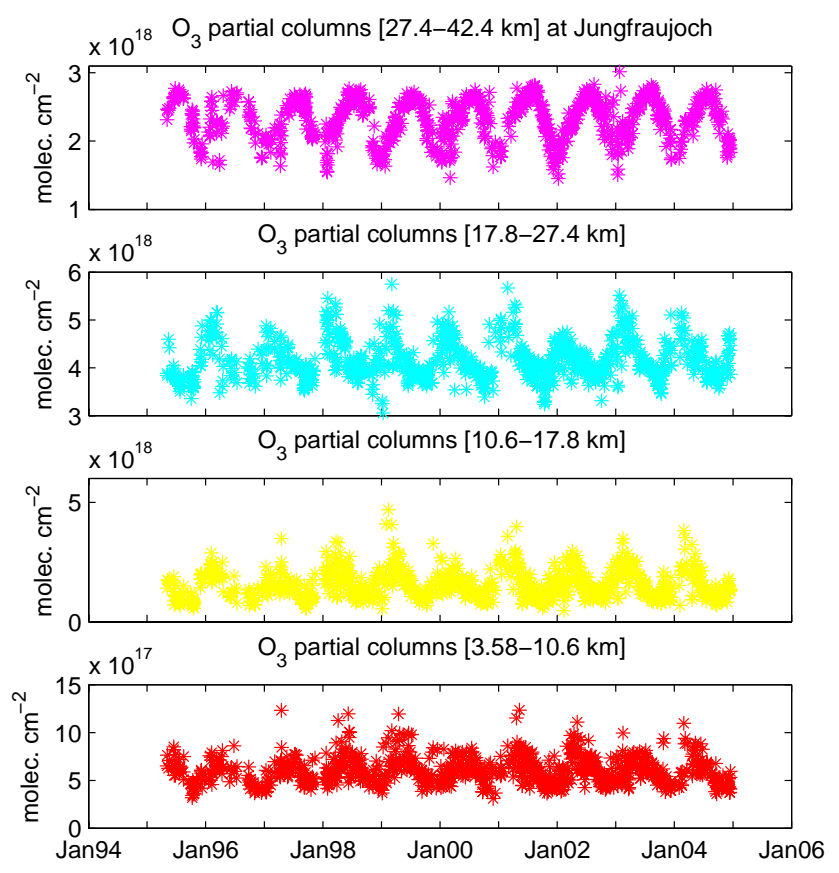

Fig. 6. Time series of $\mathrm{O}_{3}$ partial columns at Jungfraujoch.

can induce a bias as large as 3.5-4\%. However, this spectroscopic error can not explain the much larger biases observed at Harestua and Ny-Ålesund in the comparisons with UVVis data. The bias at Harestua is present in both the UV-Vis and Dobson comparisons, thus it seems that the FTIR total columns are overestimated at this station. For Ny-Ålesund, the bias between UV-Vis and FTIR measurements is most probably due to the analysis of the UV-Vis data in the UV wavelength region (336 to $357 \mathrm{~nm}$ ) applying full multiple scattering in the radiative transfer model (F. Wittrock, private communication). For up to now unknown reasons, this causes 6 to $12 \%$ smaller values for ozone depending on solar zenith angle. A new data set analysed in the visible (425 to $497 \mathrm{~nm}$ ) solves this problem and will be uploaded to the NDACC database quite soon (F. Wittrock, private communication). This interpretation is confirmed by the Dobson comparisons which show no bias for the few coincidences that were found with FTIR measurements.

Second, considering the standard deviations, we see in Table 5 that for the three stations at lowest latitude, STD is within the random error. One can even notice that the random error of the comparisons of 4.3 to $4.5 \%$ could be too conservative, as the STD is always equal to or below $3.9 \%$ for these stations. For the three stations at highest latitude, the standard deviations are larger than the random error, except for the Dobson comparisons. For Kiruna, the reason could be the higher natural variability of $\mathrm{O}_{3}$ at higher latitude that could lead to a spatial collocation problem for the comparisons with Sodankylä. Also the temporal variability could play a role in the comparisons since only daily means are compared.
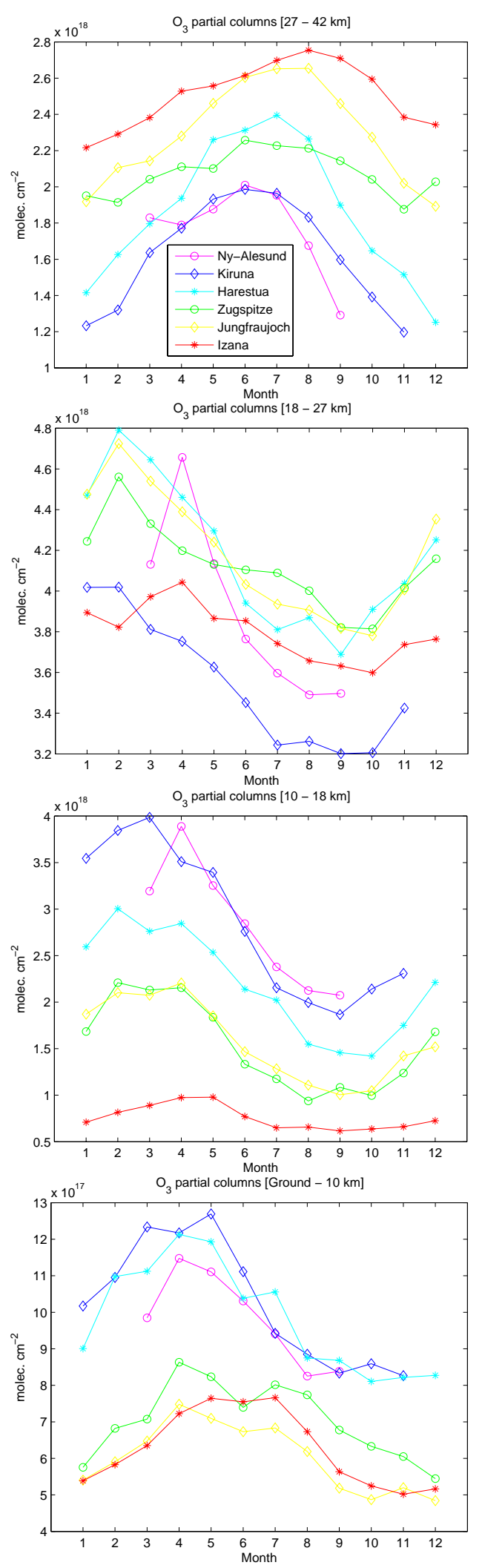

Fig. 7. Monthly means of $\mathrm{O}_{3}$ partial columns at each station. The layer limits are indicative in the figures, the exact limits are given in Table 3. 


\section{2 $\mathrm{O}_{3}$ partial columns}

\subsubsection{Partial columns time series}

We have seen in Sect. 2.3 that the DOFS is around 4.7 for $\mathrm{O}_{3}$, which justifies the definition of four partial columns (see Table 3 ) and consideration of the corresponding time series. As an example, Fig. 6 displays the partial columns time series at the Jungfraujoch station. We can notice in this figure that the timing of the seasonal maximum of ozone is different for different altitude layers. Figure 7, which shows the monthly means of partial columns at each station, illustrates this feature even better, and confirms that it exists at all stations. At the same time, it shows that the phases of the seasonal variation of ozone in each layer are slightly different with latitude.

In the upper layer $(\sim 27-42 \mathrm{~km})$, the maximum in the ozone partial column occurs in summer, shifting from early summer to late summer when going from high to low latitude. The amounts of ozone are highest for the lowest latitude station Izaña, in agreement with higher photo-chemical production of ozone at these altitudes during this season, and particularly at the latitude of Izaña.

As already mentioned in Sect. 3.1.1, the lowermost stratosphere is influenced by transport, and the large gradients in ozone amounts as a function of latitude in the $10-18 \mathrm{~km}$ layer are due to downward poleward circulation (Brasseur and Solomon, 1984). At high latitudes, the descent of air coming from the tropics occurs in winter, but this air remains in the stratosphere for several months, giving a maximum of ozone in spring in the lowermost stratosphere, and a maximum in late winter-spring in the $18-27 \mathrm{~km}$ layer.

For the tropospheric column (ground- $\sim 10 \mathrm{~km}$ ), we clearly see the difference between the mid-latitude NH broad maximum in summer and the spring maximum at the highest latitude stations. One might expect tropospheric ozone to be largest in spring, as the STE process is most effective during late winter and spring. This is indeed what is observed for the non-polluted sites of Kiruna, Ny-Ålesund and Harestua. But, as explained in Logan (1985), a broad summer maximum is present in the mid-latitude $\mathrm{NH}$, where photochemical production of ozone associated with anthropogenic sources $\left(\mathrm{NO}_{\mathrm{x}}, \mathrm{CO}\right.$, and hydrocarbons) occurs. At $\sim 30^{\circ} \mathrm{N}$, Logan (1985) reports some longitudinal differences in the seasonal cycle of tropospheric ozone, with e.g., a summer maximum in Florida and Bahamas, but not in southern Japan due to the summer monsoon. At Izaña, we see the summer maximum. We see in Fig. 7 that the differences in tropospheric ozone between the three high altitude sites (Izaña, Jungfraujoch and Zugspitze) and the others is approximately $4 \times 10^{17}$ molec. $\mathrm{cm}^{-2}$. The tropospheric ozone amounts are of course strongly affected by the different altitudes of the sites. For example, the annual mean ozone partial column in the lowest $3 \mathrm{~km}$ layer at Kiruna is about $2 \times 10^{17}$ molec. $\mathrm{cm}^{-2}$, and represents more than $20 \%$ of the tropospheric $(\mathrm{gd}-10 \mathrm{~km})$ col- umn. The high altitude of the three lowest latitude sites thus explains about half of the difference in tropospheric ozone amounts with the high latitude stations.

\subsubsection{Validation with ground-based correlative data}

Validation of FTIR ozone partial column amounts in the different layers has been made using correlative ozonesonde and Lidar data, that provide vertical profiles of $\mathrm{O}_{3}$ from the ground to about $30 \mathrm{~km}$, and from about 10 to $45 \mathrm{~km}$, respectively. The source of these correlative data is the NDACC database, except for the ozonesondes at Gardermoen which were taken from NILU Atmospheric Database for Interactive Retrieval (NADIR, http://www.nilu.no/nadir/). As done in Sect. 3.1.2 regarding the validation of ozone total columns, we have compared daily mean ozone values. To take into account the different vertical resolutions of the FTIR and correlative ozone profiles, $\boldsymbol{x}_{c}$, we have used the method of Rodgers and Connor (2003). In the present case, the vertical resolution of the ozonesondes and Lidar profiles is much higher than that of the ground-based FTIR data. Therefore the averaging kernel matrix of the correlative profiles is considered to be the identity matrix. Before comparing the correlative profiles to the FTIR ones, we smoothed them according to the characteristics of the FTIR data, following:

$\boldsymbol{x}_{s}=\boldsymbol{x}_{a}+\mathbf{A}\left(\boldsymbol{x}_{c}-\boldsymbol{x}_{a}\right)$,

in which $\boldsymbol{x}_{s}$ are the smoothed correlative profiles and $\boldsymbol{x}_{a}$ and A are the FTIR a priori profile and the FTIR averaging kernel matrix, respectively.

We give in Table 6, the statistical means (M) of the relative differences between the ozone partial columns from FTIR and correlative profiles in percent, $\mathrm{M}=$ mean(FTIRCORR)/mean(CORR), and the associated statistical $1 \sigma$ standard deviations, STD, in percent, STD $=$ std(FTIRCORR)/mean(CORR), for the partial columns defined in Table 3. The standard errors on the mean $(\operatorname{SEM}=3 \sigma / \sqrt{\mathrm{N}})$ are also given in order to detect the statistically significant biases. The random error on the differences of partial columns is calculated from Eq. (3), where $\mathbf{S}_{x}$ is the random error covariance matrix on the difference of the profiles FTIRCORR. Based on Rodgers and Connor (2003) and the fact that the averaging kernel matrix of the correlative data has been set to the unity matrix, we obtain for the random error covariance matrix of the differences:

$\mathbf{S}_{x}=\mathbf{S}_{x_{1}}+\mathbf{A} \mathbf{S}_{x_{2}} \mathbf{A}^{T}$,

with $\mathbf{S}_{x_{1}}$ the random error covariance matrix of the g-b FTIR retrieved profile and $\mathbf{S}_{x_{2}}$ the random error covariance matrix of the correlative profile, specified on the FTIR retrieval grid. The FTIR random error covariance matrix $\mathbf{S}_{x_{1}}$, which includes the noise and model parameters errors, is described in Sect. 2.4.1. The vertical smoothing error, as seen in Sect. 2.4.2, can be neglected in the comparisons as we have 
Table 6. Statistical means (M) and standard deviations (STD) of the relative differences between the $\mathrm{O}_{3}$ partial columns (PC) from the FTIR and correlative (CORR) measurements, in percentage. The correlative ozonesondes and Lidar profiles have been smoothed with the FTIR averaging kernels. The numbers of comparisons $\mathrm{N}$ involved in the different statistics are given between parentheses. The standard error on the mean $(\mathrm{SEM}=3 \mathrm{STD} / \sqrt{\mathrm{N}})$ and the random error on the comparisons are also included (in [\%]). Gd: ground.

\begin{tabular}{|c|c|c|c|c|c|c|c|}
\hline FTIR station & CORR station & PC limits $[\mathrm{km}]$ & $\mathrm{M}[\%]$ & STD $[\%]$ & $\mathrm{N}$ & SEM [\%] & Random error [\%] \\
\hline \multirow[t]{3}{*}{ Ny-Ålesund } & Sondes at Ny-Ålesund ${ }^{a}$ & $\mathrm{Gd}-9.0 \mathrm{~km}$ & +9.1 & 19.6 & (40) & 9.3 & 3.2 \\
\hline & $1995-2004$ & $9.0-17.0 \mathrm{~km}$ & +4.5 & 16.0 & (38) & 7.8 & 3.1 \\
\hline & & $17.0-27.0 \mathrm{~km}$ & -4.7 & 9.1 & $(31)$ & 4.9 & 7.5 \\
\hline \multirow[t]{6}{*}{ Kiruna } & Sondes at Sodankylä ${ }^{\mathrm{a}}$ & Gd-9.8 km & +2.9 & 17.3 & (134) & 4.5 & 2.8 \\
\hline & $1995-2004(241 \mathrm{~km})$ & $9.8-18.3 \mathrm{~km}$ & +2.7 & 21.8 & $(132)$ & 5.7 & 3.0 \\
\hline & & $18.3-27.7 \mathrm{~km}$ & -2.4 & 10.2 & (94) & 3.2 & 8.5 \\
\hline & Lidar at Andoya ${ }^{a}$ & $9.8-18.3 \mathrm{~km}$ & -7.7 & 17.2 & $(52)$ & 7.2 & 3.1 \\
\hline & $1995-2004(260 \mathrm{~km})$ & $18.3-27.7 \mathrm{~km}$ & +3.4 & 11.6 & (90) & 3.7 & 8.2 \\
\hline & & $27.7-41.6 \mathrm{~km}$ & -0.7 & 12.7 & (62) & 4.8 & 5.8 \\
\hline \multirow[t]{3}{*}{ Harestua } & Sondes at Gardermoen ${ }^{b}$ & $\mathrm{Gd}-10.6 \mathrm{~km}$ & +6.2 & 15.5 & (20) & 10.4 & 2.7 \\
\hline & 1995-2000 (20 km) & $10.6-17.6 \mathrm{~km}$ & -0.8 & 14.8 & (17) & 10.8 & 3.5 \\
\hline & & $17.6-27.6 \mathrm{~km}$ & +9.2 & 13.6 & (11) & 12.3 & 7.6 \\
\hline \multirow[t]{6}{*}{ Zugspitze } & Sondes at Hohenpeissenberg a & $\mathrm{Gd}-11.0 \mathrm{~km}$ & +0.7 & 16.6 & $(230)$ & 3.3 & 3.2 \\
\hline & $1995-2004(43 \mathrm{~km})$ & $11.0-17.9 \mathrm{~km}$ & +10.5 & 21.4 & $(230)$ & 4.2 & 3.0 \\
\hline & & $17.9-27.9 \mathrm{~km}$ & +0.6 & 6.6 & $(227)$ & 1.3 & 8.4 \\
\hline & Lidar at Hohenpeissenberg ${ }^{\text {a }}$ & $11.0-17.9 \mathrm{~km}$ & - & - & (2) & - & - \\
\hline & $1995-2004(43 \mathrm{~km})$ & $17.9-27.9 \mathrm{~km}$ & -0.4 & 6.7 & $(171)$ & 1.5 & 8.3 \\
\hline & & $27.9-41.9 \mathrm{~km}$ & +7.4 & 10.2 & $(161)$ & 2.4 & 5.1 \\
\hline \multirow[t]{6}{*}{ Jungfraujoch } & Sondes at Payerne ${ }^{a}$ & Gd-10.6 km & +3.0 & 11.0 & $(400)$ & 1.7 & 3.8 \\
\hline & 1995-2004 (84 km) & $10.6-17.8 \mathrm{~km}$ & +4.8 & 9.8 & $(400)$ & 1.5 & 3.0 \\
\hline & & $17.8-27.4 \mathrm{~km}$ & +5.2 & 3.7 & $(377)$ & 0.8 & 8.4 \\
\hline & Lidar at Hohenpeissenberg a & $10.6-17.8 \mathrm{~km}$ & - & - & $(0)$ & - & - \\
\hline & 1995-2004 (268 km) & $17.8-27.4 \mathrm{~km}$ & +7.3 & 4.3 & $(343)$ & 0.7 & 8.3 \\
\hline & & $27.4-42.0 \mathrm{~km}$ & +5.2 & 4.8 & $(329)$ & 0.9 & 5.1 \\
\hline \multirow[t]{3}{*}{ Izaña } & Sondes at Izanã ${ }^{\mathrm{a}}$ & $\mathrm{Gd}-10.7 \mathrm{~km}$ & +4.2 & 15.9 & (66) & 5.9 & 2.8 \\
\hline & 1999-2004 & $10.7-18.3 \mathrm{~km}$ & +1.5 & 22.7 & (65) & 8.4 & 2.9 \\
\hline & & $18.3-27.7 \mathrm{~km}$ & +9.6 & 4.7 & (59) & 1.9 & 8.4 \\
\hline
\end{tabular}

${ }^{\text {a }}$ Source: NDACC; ${ }^{\text {b }}$ Source: NADIR.

smoothed the correlative profiles by the FTIR averaging kernels. The $\mathbf{S}_{x_{2}}$ matrix is taken diagonal for both ozonesondes and Lidar measurements. The random error budget for the ozonesondes was not given individually in the NDACC database, thus we used typical values from the JOSIE-2000 report (Smit and Straeter, 2004): 5\% from the ground to $20 \mathrm{~km}$ and $7 \%$ above. The random errors of Lidar profiles are given individually in the data files of the NDACC database. We took the mean of the provided values for the profiles in daily coincidence with FTIR measurements. The Lidar errors can be larger than $20 \%$ at the tropopause and above $40 \mathrm{~km}$, but after the smoothing with FTIR averaging kernels in Eq. (6), they are below 5\% in the lower stratosphere, and below $10 \%$ around $40 \mathrm{~km}$.
The mean relative differences $(\mathrm{M})$ of the tropospheric layer, i.e. the biases, are lower than approximately $4 \%$ at all stations, except Harestua (6\%) and Ny-Ålesund (9\%). Considering the standard error on the mean (SEM), they are never statistically significant, except at the Jungfraujoch station, where the bias is only $+3.0 \pm 1.7 \%$ ( $M \pm S E M)$. In the lower stratospheric layer $(10-18 \mathrm{~km})$, the biases with the ozonesondes are positive but statistically non significant at all stations, except at Zugspitze (10.5 $\pm 4.2 \%)$. and Jungfraujoch $(4.8 \pm 1.5 \%)$. For this layer, the comparisons with Lidar measurements show a slightly significant negative bias at Kiruna $(-7.7 \pm 7.2 \%)$. In the $18-27 \mathrm{~km}$ layer, the biases are statistically non significant at all stations, except at Jungfraujoch $(+5.2 \pm 0.8 \%)$. and Izaña $(9.6 \pm 1.9 \%)$. We notice a good 


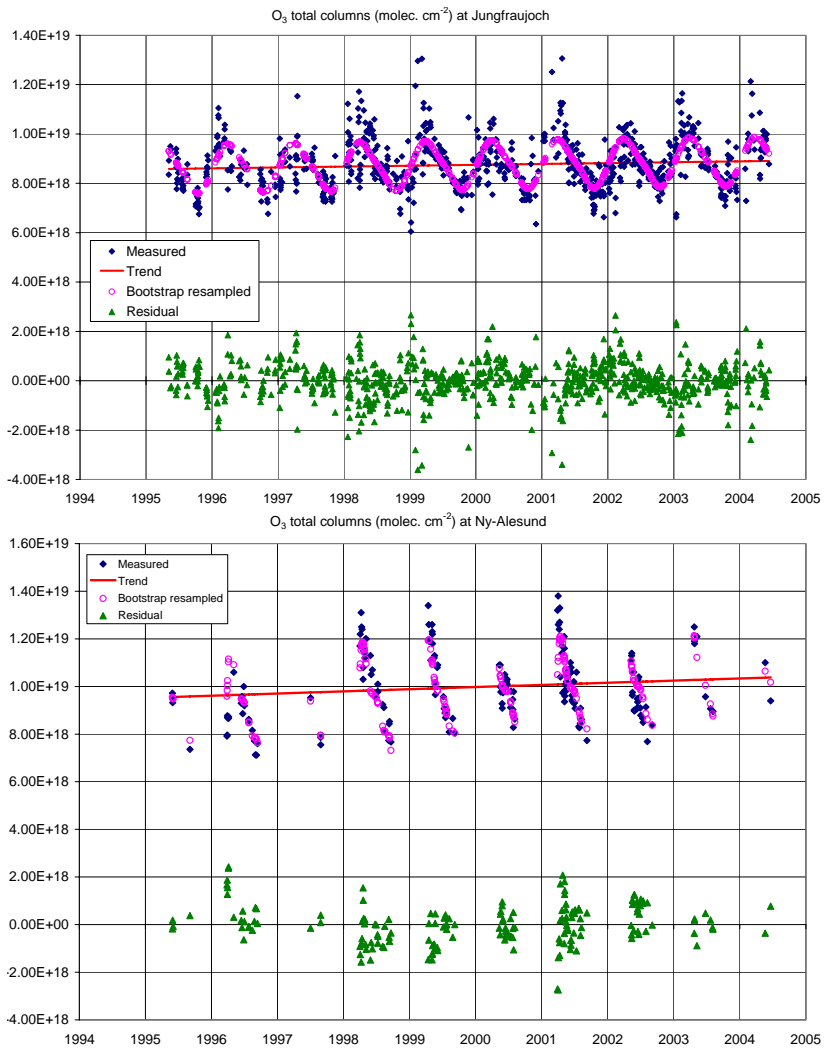

Fig. 8. Measured and bootstrap resampled ozone total columns at Jungfraujoch (top) and Ny-Ålesund (bottom). The linear trends and the residuals are also shown.

consistency between ozonesonde and Lidar comparisons. In the higher stratospheric layer $27-42 \mathrm{~km}$, the Lidar comparisons show an excellent agreement at Kiruna. Positive significant biases of $5.2 \%$ at Jungfraujoch and $7.4 \%$ at Zugspitze are observed in the comparisons between FTIR and Lidar measurements at Hohenpeissenberg. This confirms the result by Steinbrecht et al. (2006) when comparing Lidar and SAGE data: the Lidar data at this station are too low between 30 and $42 \mathrm{~km}$, with a maximum of $10 \%$ at $38 \mathrm{~km}$. We observe that in general there is a positive bias at all layers, which is in agreement with the total column comparisons showed in Table 5. The main systematic error sources for FTIR partial columns being the $\mathrm{O}_{3}$ line intensities and air broadening coefficients (Barret et al., 2002, 2003), the error on the spectroscopic parameters could partly explain the observed biases. The use of spectroscopic databases different in the present work (HITRAN 2004) and in the work of Barret et al. (2002) explains the different biases obtained, for the Jungfraujoch station, in the ozonesonde comparisons in both studies.

The standard deviations are smaller or comparable to the random errors only for the $18-27 \mathrm{~km}$ layers (with the exception of Harestua where STD is larger) and the $27-42 \mathrm{~km}$ layer at the Jungfraujoch station. In the two layers at lower altitude, the standard deviations are always larger than the random errors. In the troposphere, the standard deviations are between $11 \%$ and $20 \%$, while the random error is only between 3 and $4 \%$. In the 10-18 km layer, the standard deviations are between $10 \%$ and $24 \%$, and the random error around $3 \%$. This is not surprising considering that ozone has more variability in the tropopause region, thus we expect that the spatial and temporal differences between both measurements have a larger impact in the two lower layers.

\section{Ozone trends in Western Europe from g-b FTIR mea- surements}

Gardiner et al. (2008) describes the bootstrap resampling method that has been implemented in the UFTIR project to make statistical trend analysis of the UFTIR time series. The objective of the bootstrap analysis approach is to determine the annual trend and associated uncertainties, based on a statistical model that makes minimal assumptions about uncertainty distributions associated with the raw data. In order to capture the regular intra-annual variations in a statistically robust manner without having to make detailed assumptions about the nature of the intra-annual behaviour, a Fourier series is used to model the data. The year-to-year variability, that can appear particularly at the Arctic sites, will not be captured by the intra-annual Fourier series, but is effectively a noise source in the linear trend determination, and therefore feeds into the uncertainties in the determined trends. These uncertainties correspond to the $95 \%$ confidence interval of the bootstrap resampled distributions, which would be equivalent to $2 \sigma$ standard deviations for normal distributions (Gardiner et al., 2008). It was chosen in Gardiner et al. (2008) to use a common order Fourier series in the trend analyses for all species and all sites to give consistency in the results. The third order Fourier series provided the best overall result for all species. Generally, the variation we get in the trend and uncertainty values for different order series is significantly smaller than the basic uncertainty in the trend. In the present work, we also use third order Fourier series, for total and partial columns trends. As an example, we show in Fig. 8 the ozone total columns from the FTIR time series together with the fitted time series from the bootstrap resampling method, at Jungfraujoch and at Ny-Ålesund. The residuals and the obtained linear trends are also shown in the figure. One can see that the measured FTIR total columns are well reproduced by the third order Fourier series, even at Ny-Ålesund where the data only cover the March-September period. One should take care that the obtained trend at $\mathrm{Ny}$ Alesund concerns only this period. In the same manner, the trends given in the next sections for Kiruna concern only the January to November period. 
Gardiner et al. (2008) provides results for total, tropospheric and stratospheric column trends and associated uncertainties for the six UFTIR target species. For ozone, Gardiner et al. (2008) finds that total and stratospheric column trends are very similar, which is expected given the fact that the stratospheric column makes up $90 \%$ of the total column. In the present work, we have used the same method to derive trends for the four individual partial columns identified in Table 3 for each station. The results are presented in Table 7, where we have given only the approximate boundaries for the layers: ground- $\sim 10 \mathrm{~km}, \sim 10-18 \mathrm{~km}, \sim 18-27 \mathrm{~km}$, and $\sim 27-42 \mathrm{~km}$. The trends and their associated uncertainties are expressed as annual trends, in \% relative to the mean values for the year 2000. The small differences between the total columns trends given in Table 7 and Table 3 of Gardiner et al. (2008), come from the different definition of the total columns: from the ground up to about $100 \mathrm{~km}$ in the present work, and from the ground up to about $50 \mathrm{~km}$ in Gardiner et al. (2008).

\subsection{Total column trends}

We see from Table 7, that at the three highest latitude stations, the last decade total column ozone trends are significantly positive. We obtain $+0.92 \pm 0.64,+0.64 \pm 0.39$, and $0.56 \pm 0.48 \% / \mathrm{yr}(\sim 3.4 \pm 2.3,2.1 \pm 1.3,2.0 \pm 1.8 \mathrm{DU} / \mathrm{yr})$ for Ny-Ålesund, Kiruna, and Harestua, respectively. This is in agreement with Weatherhead and Andersen (2006) who report an increase of about 2.5 and $2 \mathrm{DU} / \mathrm{yr}$ at latitudes $80^{\circ} \mathrm{N}$ and $60-70^{\circ} \mathrm{N}$, respectively, for 1996-2004, based on merged TOMS/SBUV2 satellite data. The high variability of ozone in the Arctic, mainly driven by changes in dynamics, makes it difficult to detect and interpret a possible turnaround in the ozone trend at these latitudes (WMO, 2006). Therefore, it is too early to explain the observed positive trends at $\mathrm{NH}$ high-latitudes by the decrease of EESC. They could rather be due to the higher occurrence of warmer winters that appeared since 1997/1998 in the Arctic compared to the previous period 1991-1997 (Manney et al., 2005), and that leads to less ozone depletion during these warm winters/springs. To demonstrate this, we have calculated the total ozone trend at Harestua, for the 1995-2005 period, as one more year of data was already available for that station, and we found a reduced and non significant trend of $0.14 \pm 0.43 \% / \mathrm{yr}$. Indeed, the very cold winter/spring 2004/2005 in the Arctic leads to large ozone loss (Manney et al., 2006), as observed for Harestua in Fig. 4, with lower ozone values during spring 2005 compared to $1997-2004$ springs. This gives an example of the strong influence of the temperature, which is linked to planetary wave activity (Dhomse et al., 2006), on the trends in the Arctic.
The total ozone trend at Izaña is small and non significant $(-0.08 \pm 0.28 \% / y r)$, in agreement with previous studies for latitudes around $20-30^{\circ} \mathrm{N}$ using TOMS/SBUV data (Reinsel et al., 2005; Andersen et al., 2006).

At the two mid-latitude stations, one observes small positive trends in total ozone, significant for Jungfraujoch $(0.41 \pm 0.21 \% / \mathrm{yr} \sim 1.32 \pm 0.69 \mathrm{DU} / \mathrm{yr})$ and not significant for Zugspitze $(0.15 \pm 0.29 \% / \mathrm{yr} \sim 0.47 \pm 0.91 \mathrm{DU} / \mathrm{yr})$. Based on TOMS/SBUV data, Reinsel et al. (2005) obtain a significant positive trend of $1.73 \pm 0.57 \mathrm{DU} / \mathrm{yr}$ for the period after the turnaround in 1996 up to 2002 , for the $45-50^{\circ} \mathrm{N}$ latitude band. Our results are in agreement with the observation of a turnaround in the negative trend of mid-latitude total ozone: an ozone minimum is observed in 1993, with particular low ozone values mainly due to the Mt. Pinatubo volcanic eruption, and a turnaround point is often chosen around 1996 for trend studies (Stolarski and Frith, 2006; Dhomse et al., 2006; Andersen et al., 2006; Reinsel et al., 2005). As discussed in these previous studies, it is still under debate whether the turnaround is due to declining EESC, because the total ozone trends are also influenced by solar activity (11-year cycle), volcanic eruptions, temperature, and dynamical processes (Brewer-Dobson circulation and nonlinear synoptic wave forcing). Also, the positive ozone trends in the Arctic, associated with the recent warmer winters, play a role in the mid-latitude positive trends: it was shown that the transport of ozone-depleted air from the polar vortex has an influence on the longitudinal differences in past negative ozone trends at mid-latitudes (Andersen and Knudsen, 2006). Quantifying the individual contributions of the processes that drive ozone trends is very complex and a great challenge for modelling studies. Since these contributions are dependent on altitude, it is very useful to investigate the vertical distribution of ozone trends.

\subsection{Middle-upper stratosphere $(27-42 \mathrm{~km})$ trends}

Table 7 shows that the trends for the upper layer $(27-42 \mathrm{~km})$ resulting from our study are quite different according to the station.

We detect significant positive trends at the high latitude stations Kiruna and Harestua, but not at Ny-Ålesund. The lack of measurements at Ny-Ålesund during polar night could explain partly the apparent disagreement with the two other high latitude stations. Indeed, if we reduce the Kiruna and Harestua data to the March-September period, reduced trends are obtained, nonetheless still significantly positive: $1.06 \pm 0.41 \% / \mathrm{yr}$ and $1.78 \pm 0.69 \% / \mathrm{yr}$, respectively. A change in Brewer-Dobson circulation, which is active in winter in the middle-upper stratosphere at high latitudes, could be responsible for a seasonal dependence in the observed trends. Unfortunately, there are too few studies regarding upper stratospheric ozone trends in the Arctic to corroborate our results. 
Table 7. Annual $\mathrm{O}_{3}$ trends and uncertainties (95\% confidence limits) in ground- $\sim 10 \mathrm{~km}, \sim 10-18 \mathrm{~km}, \sim 18-27 \mathrm{~km}, \sim 27-42 \mathrm{~km}$ and total columns (as \% of 2000 value). The exact boundaries of the layers are given in Table 3. The measurements at Ny-Ålesund and Kiruna are restricted to the March-September and January-November periods, respectively.

\begin{tabular}{lccccccc}
\hline FTIR station & Latitude & Period & Ground- $10 \mathrm{~km}$ & $\sim 10-18 \mathrm{~km}$ & $\sim 18-27 \mathrm{~km}$ & $\sim 27-42 \mathrm{~km}$ & Total \\
\hline Ny-Ålesund & $79^{\circ} \mathrm{N}$ & $1995-2004$ & $-0.03( \pm 0.92)$ & $1.99( \pm 1.31)$ & $0.86( \pm 0.82)$ & $-0.13( \pm 0.67)$ & $0.92( \pm 0.64)$ \\
Kiruna & $68^{\circ} \mathrm{N}$ & $1996-2004$ & $0.36( \pm 0.51)$ & $0.27( \pm 0.78)$ & $0.63( \pm 0.46)$ & $1.45( \pm 0.44)$ & $0.64( \pm 0.39)$ \\
Harestua & $60^{\circ} \mathrm{N}$ & $1995-2004$ & $-0.81( \pm 0.69)$ & $-1.36( \pm 1.15)$ & $1.03( \pm 0.43)$ & $3.06( \pm 0.73)$ & $0.56( \pm 0.48)$ \\
Zugspitze & $47^{\circ} \mathrm{N}$ & $1995-2004$ & $0.09( \pm 0.74)$ & $2.03( \pm 1.49)$ & $-0.01( \pm 0.30)$ & $-0.50( \pm 0.32)$ & $0.15( \pm 0.29)$ \\
Jungfraujoch & $47^{\circ} \mathrm{N}$ & $1995-2004$ & $0.22( \pm 0.49)$ & $1.08( \pm 0.76)$ & $0.30( \pm 0.17)$ & $0.26( \pm 0.18)$ & $0.41( \pm 0.21)$ \\
Izaña & $28^{\circ} \mathrm{N}$ & $1999-2004$ & $-0.62( \pm 0.77)$ & $-0.43( \pm 1.72)$ & $0.58( \pm 0.30)$ & $-0.82( \pm 0.38)$ & $-0.08( \pm 0.28)$
\end{tabular}

At Izaña, the upper layer trend is significantly negative $(-0.82 \pm 0.38 \% / \mathrm{yr})$. We can notice a longitudinal difference with the significant positive trend $(0.194 \pm 0.189 \% / \mathrm{yr})$ obtained at Hawai $\left(19.5^{\circ} \mathrm{N},-155.6^{\circ} \mathrm{E}\right)$ for the $35-45 \mathrm{~km}$ layer and the period 1997-2005 from Lidar and microwave measurements (Steinbrecht et al., 2006). No other studies are available for these altitudes in the subtropics, and reasons for this longitudinal difference should be investigated. However, other experiments confirm our results: at Izaña, ECC sondes are launched weekly and high quality Brewer measurements are performed continuously since 1992. The ECC sondes show no significant trend below $18 \mathrm{~km}$, but a significant positive trend for the $18-27 \mathrm{~km}$ layer $(0.61 \pm 0.22 \% / \mathrm{yr})$ for the period 1992-2006 (A. Redondas, private communication, trends are obtained according to Reinsel et al., 2002). This increase is not observed in the total $\mathrm{O}_{3}$ trends obtained from the Brewer data $(0.12 \pm 0.16 \% / y r)$ for the same period (A. Redondas, private communication). These two observations support the negative trend found in the FTIR data for the $27-42 \mathrm{~km}$ layer.

At the two mid-latitude stations, the trends are small but significant, and of different signs: negative at Zugspitze $(-0.50 \pm 0.32 \% / \mathrm{yr} \sim-0.42 \pm 0.27 \mathrm{DU} / \mathrm{yr})$ and positive at Jungfraujoch $(+0.26 \pm 0.18 \% / \mathrm{yr} \sim+0.22 \pm 0.15 \mathrm{DU} / \mathrm{yr})$. Both results are consistent, within their uncertainties, with the study of Yang et al. (2006), which obtains $+0.06 \pm 0.31 \mathrm{DU} / \mathrm{yr}$, for columns above $25 \mathrm{~km}$ from SAGE satellite measurements between 30 and $60^{\circ} \mathrm{N}$ for the $1997-$ 2005 period. However, it is surprising to obtain trends that do not agree within their uncertainties for stations that are very close $(318 \mathrm{~km})$ to each other. A similar situation was noticed by Steinbrecht et al. (2006) who obtained a negative ozone trend in the $35-45 \mathrm{~km}$ altitude range at Hohenpeissenberg $\left(48^{\circ} \mathrm{N}, 11^{\circ} \mathrm{E}\right)$ but not in Haute Provence $\left(44^{\circ} \mathrm{N}, 6^{\circ} \mathrm{E}\right)$. Steinbrecht et al. (2006) suggested that the negative trend at Hohenpeissenberg was due to record low stratospheric ozone values in the winters 2003/2004 and 2004/2005. If we limit the evaluation of trends to the 1995-2002 period, we find indeed a better agreement between both stations with $+0.27 \pm 0.48 \% / \mathrm{yr}$ and $+0.28 \pm 0.24 \% / \mathrm{yr}$ for Zugspitze and Jungfraujoch, respectively. Thus, the last two winters at Zugspitze $\left(47^{\circ} \mathrm{N}, 12^{\circ} \mathrm{E}\right), 2002 / 2003$ and $2003 / 2004$ (the Zugspitze time series ends in September 2004), where particularly low ozone partial columns occur in the $27-42 \mathrm{~km}$ range, have a quite important influence on the associated trend. For about 25 days out of the 35 days when lowest values were seen at Zugspitze during these two winters, there are no data at Jungfraujoch, probably due to bad weather conditions. These winter values have a large impact on the trend evaluation, most likely because the Zugspitze time series contains less data during the first years of measurements, especially in winters. This is illustrated in Fig. 9. The difference in the upper stratospheric ozone trends at both stations is, for a large part, responsible for the difference in the total ozone trends seen in previous section. It is worth noticing that another study regarding Umkher data at Arosa $\left(47^{\circ} \mathrm{N}, 10^{\circ} \mathrm{E}\right)$ (Zanis et al, 2006) has shown a negative trend in the $32.6-37.5 \mathrm{~km}$ layer of $-0.38 \pm 0.25 \% / \mathrm{yr}$ for the $1996-$ 2004 period, and $-0.30 \pm 0.27 \% /$ decade for the layer above $37.5 \mathrm{~km}$.

The causes of the observed levelling off or even of the "turnaround" of the past negative upper stratospheric ozone trend in NH mid-latitudes around 1996, are not well distinguished up to now. At these high altitudes where chemistry plays a major role, the change in EESC amounts is in competition with the end of the solar maximum (11-year cycle), as were debating Newchurch et al. (2003); Steinbrecht et al. (2004a); Cunnold et al. (2004); Steinbrecht et al. (2004b). The two solar maxima before 1999-2003 coincide with large volcanic eruptions, and the 1999-2003 solar 
maximum coincides with a decrease in ODSs: more years of measurements are needed to distinguish the effect of the solar cycle on ozone (WMO, 2006). More recently, the study of Yang et al. (2006), based on a model constrained by satellite observations, indicated chemical processes, driven by the EESC decrease, as the major cause of the levelling off of the ozone upper stratospheric trends in the last decade, with a $30 \%$ contribution to the total ozone trends. This is in contradiction with Dhomse et al. (2006) who concluded that EESC changes had a minor impact on the recent total column ozone trends.

\subsection{Lower-middle stratosphere $(18-27 \mathrm{~km})$ trends}

In the 18-27 km layer, ozone trends are significantly positive at all stations, except Zugspitze where the trend is near zero (see Table 7).

The significant positive trends at Kiruna and Harestua, of $0.63 \pm 0.46 \% / \mathrm{yr}$ and $1.03 \pm 0.43 \% / \mathrm{yr}$, respectively, seem to disagree with the results obtained by Kivi et al. (2007) at seven ozonesonde stations in the Arctic (from $60^{\circ} \mathrm{N}$ to $80^{\circ} \mathrm{N}$ ), four in Europe and three in Canada. This study pointed to non significant trends in the 40-10 hPa layer for the period 1996-2003. Even if we limit the time period for the evaluation of our trends to this same period, we find significant positive trends. But if we use a layer that corresponds better to the 40-10 hPa range at Kiruna (around 21-29 km), which contains a DOFS of 1.04, we then obtain a trend of $0.54 \pm 0.55 \%$ which is indeed non significant. The reason for this result is that the positive trend is actually situated in the $16-22 \mathrm{~km}$ layer $(0.70 \pm 0.55 \%$, DOFS $=1.1)$. The same behaviour is observed at Harestua: the trend for the 22-29 km layer is smaller than for the $18-27 \mathrm{~km}$ layer, even if it remains significant in this case $(0.93 \pm 0.67 \% / \mathrm{yr}$, DOFS $=0.9)$. At Ny-Ålesund also, the trend is non significant in the 21$29 \mathrm{~km}$ layer. Unfortunately, we cannot compare the trend at Ny-Ålesund to the Kivi et al. (2007) results since in our case it represents the March to September trend, while Kivi et al. (2007) show very contrasted results depending on season and do not include the whole March to September one.

Also at Izaña, we obtain a significant positive trend of $0.58 \pm 0.30 \% / y r$. The literature does not provide easily comparable results for that latitude, altitude and time period, since we only found SAGE and SBUV trends for the complete 1979-2004 period (WMO, 2006). However, as mentioned in the previous section, the ECC sondes at Izaña show a significant positive trend for the $18-27 \mathrm{~km}$ layer $(0.61 \pm 0.22 \% / y r)$ for the period 1992-2006 (A. Redondas, private communication).

For the two mid-latitude stations, we obtain a zero trend $(-0.01 \pm 0.30 \% / \mathrm{yr})$ at Zugspitze, and a significantly positive trend at Jungfraujoch $(0.30 \pm 0.17 \% / \mathrm{yr})$ in the $18-27 \mathrm{~km}$ layer. Both results agree with the observation of a levelling off of the past slightly negative trend around $30 \mathrm{~km}$, since 1993-1996 (WMO, 2006). Previous studies at NH mid-
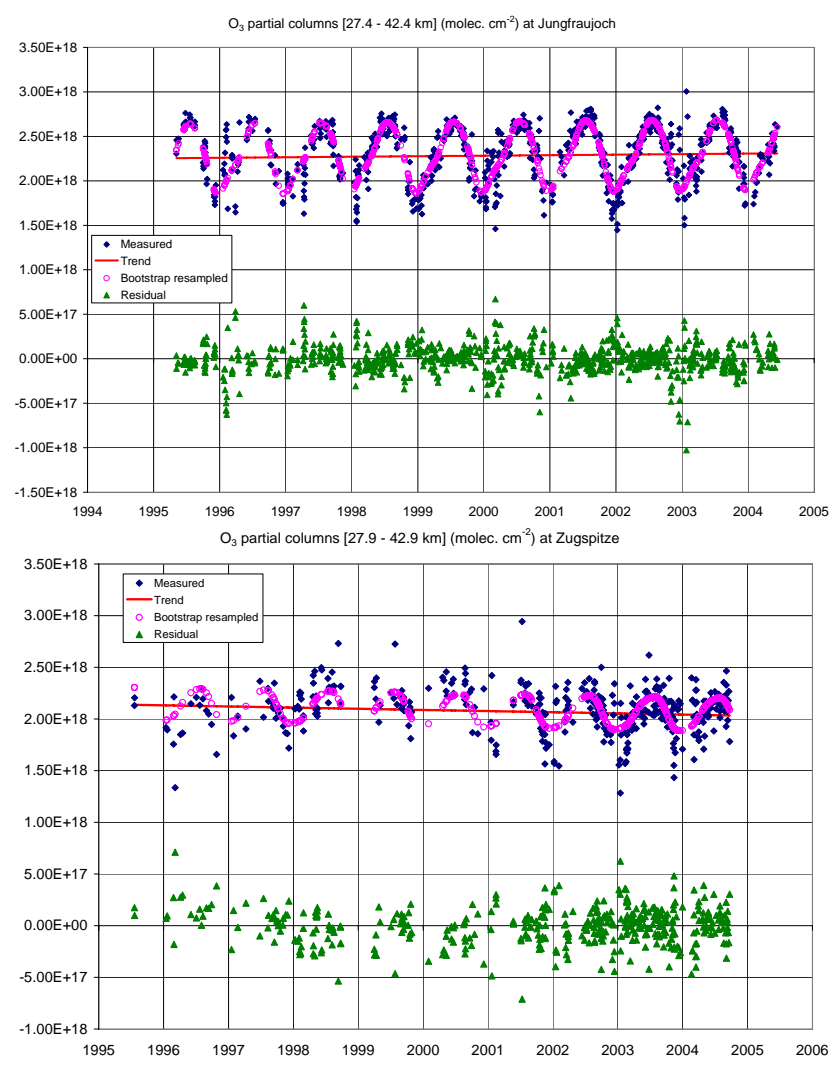

Fig. 9. Measured and bootstrap resampled ozone partial columns ( $\sim 27-42 \mathrm{~km}$ ) at Jungfraujoch (top) and Zugspitze (bottom). The linear trends and the residuals are also shown.

latitudes (Miller et al., 2006; Yang et al., 2006) obtained non significant trend, in the $18-25 \mathrm{~km}$ layer for the 19962005 period. From the study by Yang et al. (2006), the trend change at these altitudes would also be due to the levelling off of EESC, rather than to dynamical changes, rising to about $50 \%$ the total (18-25 km layer and upper stratosphere) contribution of EESC changes to total column ozone trends.

\subsection{Near-tropopause/lowermost stratosphere (10-18 km) trends}

Regarding the trends in the lower stratosphere (10 to $18 \mathrm{~km}$ altitude), we see in Table 7, that the results are quite different for the three high latitude stations. The high positive trend at Ny-Ålesund for the March-September period $(1.99 \pm 1.31 \% / y r)$ could be explained by the warmer winters that occurred since 1997/1998 leading to less ozone depletion in late winter / early spring at this station, in a similar way to the total column trend. This effect is less clear at Kiruna, where the trend of this ozone layer is much smaller and non significant $(0.27 \pm 0.78 \% / \mathrm{yr})$. However, the trends at these two stations are in agreement within their uncertainties and with the work of Kivi et al. (2007). The latter study obtains, 
for the period 1996-2003, positive trends of $1.34 \pm 1.26 \% / \mathrm{yr}$ for the tropopause- $150 \mathrm{hPa}$ layer and $1.25 \pm 0.78 \% / \mathrm{yr}$ for the 150-40 hPa layer for all seasons, and higher trends in the January-April period. For the same reason than in previous section (the positive trend is located in the 16$22 \mathrm{~km}$ layer), the trend at Kiruna for a layer corresponding to the tropopause $-40 \mathrm{hPa}$ (around $11-21 \mathrm{~km}$ ) is higher $(0.47 \pm 0.65 \% / \mathrm{yr}, \mathrm{DOFS}=1.6)$, but in our case it remains non significant. For Kivi et al. (2007), this large change relative to the past negative trend in the lowermost stratosphere layer can be primarily attributed to dynamical changes.

The trend at Harestua is large and negative $(-1.60 \pm 0.90 \% / \mathrm{yr})$, which looks in contradiction with the other stations and Kivi et al. (2007). At present no explanation is found for that behaviour, thus results from this station should be taken with care. It could be that the high DOFS (5.6) obtained for that station compared to the other ones (Table 3 ) is somehow unrealistic and indicates that the retrievals were not sufficiently constrained.

In the $10-18 \mathrm{~km}$ layer at Izaña, which is the layer around the tropopause for this low latitude station, we obtain a negative but non significant trend $(-0.43 \pm 1.72 \% / y r)$, in agreement with ECC sondes at Izaña (A. Redondas, private communication). In the subtropics, the only long-term records at these altitudes come from SAGE measurements, whereas in the tropics ozonesonde data are also available from the SHADOZ (Southern Hemisphere Additional Ozonesondes) network since 1998. Randel et al. (2006) have compared the SAGE II ozone between $16-18 \mathrm{~km}$ and $20^{\circ} \mathrm{S}-20^{\circ} \mathrm{N}$ to the mean of seven SHADOZ stations. They agree well in detecting a negative trend for the period 1998-2004. Randel et al. (2006) attributes this decrease in ozone near the tropical tropopause to an increase in the mean upwelling (BrewerDobson) circulation. As this study does not observe a decrease in ozone for lower altitudes, the authors do not consider an increase in deep convection is plausible. In our case, if we limit the partial columns to $10-15 \mathrm{~km}$, and to $15-18 \mathrm{~km}$, it seems indeed that the negative trend is located in the second layer and not in the lowest altitude, but it is still non significant $(0.58 \pm 1.53 \% / \mathrm{yr}$ and $-1.36 \pm 2.10 \% / \mathrm{yr}$ for $10-15 \mathrm{~km}$ and $15-18 \mathrm{~km}$, respectively). One should take care as the DOFS is less than 1 in these layers (only about 0.5), which limits the interpretation of these results. On the contrary, Solomon et al. (2005) find, from 2 long-term ozonesondes time series in the tropical Pacific region, that the frequency of reduced or near-zero ozone events between $\sim 8-15 \mathrm{~km}$ has increased since the mid-1990s, and concludes that the frequency of deep convection has increased since then.

The trends in the lowermost stratosphere at the two mid-latitude stations, Jungfraujoch and Zugspitze, turn out to be high and significantly positive, equal to $1.08 \pm 0.76 \% / \mathrm{yr} \quad(\sim 0.59 \pm 0.41 \mathrm{DU} / \mathrm{yr})$ and $2.03 \pm 1.49 \% / \mathrm{yr}$ $(\sim 0.88 \pm 0.64 \mathrm{DU} / \mathrm{yr})$, respectively. These high values and the fact that the trends are larger in this layer than in the 18$27 \mathrm{~km}$ layer are in agreement with ozonesondes studies at
NH mid-latitudes (Miller et al., 2006; Yang et al., 2006), and Umkehr measurements at Arosa (Zanis et al, 2006). Yang et al. (2006) find that the positive trend of $0.59 \pm 0.55 \mathrm{DU} / \mathrm{yr}$ in the tropopause- $18 \mathrm{~km}$ layer, obtained from 11 ozonesondes between 30 and $60^{\circ} \mathrm{N}$, contributes $50 \%$ to the total column trends and is mainly due to trends in dynamical processes. Also, Miller et al. (2006) find that the influence of the Arctic Oscillation is statistically significant. The highly negative past trend at mid-latitude in the lowermost stratosphere was attributed for an important part to the export of polar ozone loss (Chipperfield, 2003); similarly, the positive ozone trends observed over the 1995-2005 period in the Arctic stations probably contribute to the positive trend, observed in the lowermost stratosphere over the same period, at the midlatitude stations.

In conclusion, the dynamical changes that make ozone increase in the lowermost stratosphere contribute to the fact that the total ozone trends changes in the $\mathrm{NH}$ mid-latitudes appeared quicker than expected on the basis of only the EESC decline (WMO, 2006; Reinsel et al., 2005; Weatherhead and Andersen, 2006). The causes of the trends in the lower stratospheric circulation are unclear. It could be due to natural climate variability or climate change due to increasing greenhouse gases (WMO, 2006).

\subsection{Tropospheric ozone}

As the FTIR retrievals have only one DOFS in the troposphere, we can not have separate trends for the boundary layer and the free troposphere. In this study, the upper boundary is not the tropopause, as it is the case in Gardiner et al. (2008), but an altitude between 9 and $11 \mathrm{~km}$, chosen to give at least one DOFS between the ground and the upper boundary.

It is clear from Table 7 that the trends in the troposphere are non significant, except at Harestua where it is significantly negative. This negative trend at Harestua is also observed in the CTM2 model simulations as shown in Gardiner et al. (2008), and the reason for it is not yet understood.

Within their uncertainties, the trends at the two high latitude stations Ny-Ålesund and Kiruna, $-0.03 \pm 0.92 \% / y r$ and $0.36 \pm 0.51 \% / \mathrm{yr}$, respectively, are in agreement with the value of $0.31 \pm 0.30 \% / \mathrm{yr}$ obtained by Kivi et al. (2007), for the ground-400 hPa layer, and for the 1996-2003 period. Kivi et al. (2007) attribute the observed positive trends in tropospheric ozone to changes in the Arctic Oscillation, that regulates the transport of ozone and its precursors from polluted areas toward the pole, and that may also influence the STE. Tarasick et al. (2005) also show a significant correlation between the lower stratospheric and tropospheric trends from ozonesondes in Canada $\left(53-83^{\circ} \mathrm{N}\right)$ that could come from STE processes or from the effect of stratospheric ozone on UV-induced photochemical destruction of tropospheric ozone. 
At Izaña $\left(28^{\circ} \mathrm{N}\right)$, we obtain a negative but non significant ozone trend in the troposphere of $-0.62 \pm 0.77 \% / y r$. Not much is known about the tropospheric ozone trends in the tropics and subtropics due to the lack of measurements. Some inconsistencies exist between the trends derived from MOZAIC aircraft measurements on the one hand and from SHADOZ ozonesondes on the other hand (WMO, 2006). Indeed, Bortz et al. (2006) report an increase of $20 \%$ in upper tropospheric tropical ozone for the 1994-2003 period from MOZAIC measurements. This increase is attributed to an increase in ozone precursors. On the contrary, Randel et al. (2006) deduces no significant trend from SHADOZ measurements below $14 \mathrm{~km}$. Furthermore, as seen in the previous section, Solomon et al. (2005) observe a higher frequency of reduced or near-zero ozone events in the upper troposphere in tropical southwest Pacific stations. The above uncertainties and apparent inconsistencies highlight the importance of additional independent data in the tropical regions such as the FTIR at Izaña. As seen previously, sondes measurements at Izaña are also giving a non significant trend in the troposphere (A. Redondas, private communication).

The non significant trends of tropospheric ozone that we observe at Zugspitze and Jungfraujoch, of $0.09 \pm 0.74 \% / \mathrm{yr}$ and $0.22 \pm 0.44 \% / y r$, respectively, are in agreement with previous studies that show a levelling off of the increase in tropospheric ozone in Europe due to the decline of anthropogenic ozone-precursors. Ozonesondes studies show, in the two last decades, a slightly decreasing tropospheric ozone trend at Hohenpeissenberg (Oltmans et al., 2006) and a zerotrend at Payerne and Uccle (WMO, 2006) in agreement with the decreasing emissions.

\section{Conclusions}

The NDACC network includes six ground-based FTIR stations in Western Europe, covering the $79^{\circ} \mathrm{N}$ to $28^{\circ} \mathrm{N}$ latitudes. Within the European project UFTIR (Time series of Upper Free Troposphere observations from a European ground-based FTIR network), these stations have reanalysed their ozone spectral time series for the period 1995-2004, using a retrieval strategy that optimizes the vertical information content. As such, it has been possible to provide time series of ozone partial columns in four independent layers in the atmosphere, in addition to total column amounts. A bootstrap resampling method has been applied to determine the corresponding total and partial column annual trends.

We have first demonstrated the reliability of the groundbased long-term FTIR measurements for providing total column ozone trends. Indeed, the trends derived from the FTIR data for the period 1995-2004 are in agreement with previous studies based on satellite data. There is no significant total ozone trend at the subtropical station Izaña $\left(28^{\circ} \mathrm{N}\right)$. Slightly positive total column trends are seen at the two mid-latitude stations Zugspitze and Jungfraujoch $\left(47^{\circ} \mathrm{N}\right)$, only one of them being significant. The highest latitude stations Harestua

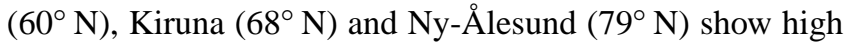
and significant positive total column trends, of $0.56,0.64$ and $0.92 \% / y r$, respectively.

Secondly, we have investigated the time series and associated trends of ozone partial columns in four independent layers, as derived from the FTIR measurements using the optimal estimation method. The separate trends can help to distinguish the contributions from dynamical and chemical (EESC) changes on the total column ozone trends. Since we find higher and positive ozone trends in the lowermost stratosphere $(10-18 \mathrm{~km})$ at the two NH mid-latitude stations compared to the upper stratospheric layer $(27-42 \mathrm{~km})$, our results seem to confirm that transport changes are the dominant contribution to the total column trends at mid-latitude. The enhanced ozone observed in polar stations is also contributing to the increase in mid-latitude ozone (Dhomse et al., 2006). A reason for the high positive trends at high latitude is the occurrence of warmer winters in the Arctic in the considered period, linked to changes in the planetary wave activity (Dhomse et al., 2006). The high positive upper stratosphere trend observed at Kiruna and Harestua indicates probably a contribution from EESC decline. The trends seems to be even higher in winter, since a non significant trend is seen in the $27-42 \mathrm{~km}$ layer at $\mathrm{Ny}$-Ålesund where solar measurements are impossible in polar winter. This would support also a contribution from changes in the Brewer-Dobson circulation, which is active in winter at these altitudes. To understand whether these dynamical changes are due to natural variability or climate change, and to distinguish also the respective effect of the 11-year solar cycle and the EESC decline on ozone trends, further years of observations would be required. To explain some regional or longitudinal differences in the trends, such as the differences in upper stratospheric trends at Jungfraujoch and Zugspitze, or at Izaña and Hawaï (Steinbrecht et al., 2006), could also be a challenge for modelling studies. We find significant positive trends for the 18-27 km layer at Kiruna, Harestua, Jungfraujoch, and Izaña. With the exception of Harestua, none of the groundbased stations displays a statistically significant trend in the troposphere. This is an interesting result, because different studies have reported various, not necessarily compatible trend results.

When comparing with literature, the ozone trends obtained in the present work seem robust, even for the quite short period considered (1995-2004). This demonstrates that the continuation of the NDACC FTIR measurements will provide an appropriate data set for the study of the total column ozone trends and their vertical distribution, from the ground up to about $42 \mathrm{~km}$.

Acknowledgements. We acknowledge financial support within the EU projects UFTIR and SCOUT-O3. The FTIR measurements at Ny-Ålesund received national financial support from the Helmholtz Association within the institute PEP. We thank also the International Foundation High Altitude Research Stations Jungfraujoch 
and Gornergrat (HFSJG, Bern) for hosting the Liège laboratory and providing accommodation for the observers at the Jungfraujoch site. We further acknowledge the vital contribution from all colleagues in performing the ground-based observations used here. The data used for validation in this publication are publicly available at the Network for the Detection of Atmospheric Composition Change (NDACC, http://www.ndacc.org/), the World Ozone and Ultraviolet Radiation Data Centre (WOUDC, http://www.woudc.org/), the Envisat Validation Database (CALVAL, http://nadir.nilu.no/calval/), and the NILU Atmospheric Database for Interactive Retrieval (NADIR, http://www.nilu.no/nadir/). We thank all the data providers that made the validation part possible, and particularly P. von der Gathen (AWI), E. Kyrö (FMI), H. Claude (DWD), U. Köhler (DWD), W. Steinbrecht (DWD), and F. Wittrock (IUP, Bremen) for their useful comments. We thank also A. Redondas (INM) for providing his results on ECC sondes and Brewer ozone trends at Izaña, and K. Ellingsen (U. of Oslo) and M. Gauss (U. of Oslo) for providing CTM2 model data used for building the ozone covariance matrix at Zugspitze.

Edited by: S. Wood

\section{References}

Andersen, S. B. and Knudsen, B. M.: The influence of polar vortex ozone depletion on $\mathrm{NH}$ mid-latitude ozone trends in spring, Atmos. Chem. Phys., 6, 2837-2845, 2006,

http://www.atmos-chem-phys.net/6/2837/

2006/http://www.atmos-chem-phys.net/6/2837/2006/.

Andersen, S. B., Weatherhead, E. C., Stevermer, A., Austin, J., Brühl, C, Fleming, E. L., de Grandpré, J., Grewe, V., Isaksen, I., Pitari, G., Portmann, R. W., Rognerud, B., Rosenfield, J. E., Smyshlyaev, S., Nagashima, T., Velders, G. J. M., Weisenstein, D. K., and Xia, K.: Comparison of recent modeled and observed trends in total column ozone, J. Geophys. Res., 111, D02303, doi:10.1029/2005JD006091, 2006.

Barret, B., De Mazière, M., and Demoulin, P.: Retrieval and characterization of ozone profiles from solar infrared spectra at the Jungfraujoch, J. Geophys. Res., 107(D24), 4788, doi:10.1029/2001JD001298, 2002.

Barret, B., De Mazière, M., and Demoulin, P.: Correction to "Retrieval and characterization of ozone profiles from solar infrared spectra at the Jungfraujoch”, J. Geophys. Res., 108(D12), 4372, doi:10.1029/2003JD003809, 2003.

Bortz, S. E., Prather, M. J., Cammas, J.-P., Thouret, V., and Smit, H.: Ozone, water vapor, and temperature in the upper tropical troposphere: Variations over a decade of MOZAIC measurements, J. Geophys. Res., 111, D05305, doi:10.1029/2005JD006512, 2006.

Brasseur, G. and Solomon, S: Aeronomy of the Middle Atmosphere, 441 pp., D. Reidel Publishing Company, Dordrecht, The Netherlands, 1984.

Chipperfield, M. P.: A three-dimensional model study of longterm mid-high latitude lower stratosphere ozone changes, Atmos. Chem. Phys., 3, 1253-1265, 2003,

http://www.atmos-chem-phys.net/3/1253/2003/.

Cunnold, D. M., Yang, E.-S. , Newchurch, M. J., Reinsel, G. C., Zawodny, J. M., and Russell III, J. M.: Comment on "Enhanced upper stratospheric ozone: Sign of recovery or solar cycle ef- fect?” by W. Steinbrecht et al., J. Geophys. Res., 109, D14305, doi:10.1029/2004JD004826, 2004.

Daniel, J. S., Solomon, S., and Albritton, D. L.: On the evaluation of halocarbon radiative forcing and global warming potentials, J. Geophys. Res., 100(D1), 1271-1286, 1995.

De Mazière, M., Vigouroux, C., Gardiner, T., Coleman, M., Woods, P., Ellingsen, K., Gauss, M., Isaksen, I., Blumenstock, T., Hase, F., Kramer, I., Camy-Peyret, C., Mondelain, D., Mahieu, E., Demoulin, P., Duchatelet, P., Mellqvist, J., Strandberg, A., Velazco, V., Notholt, J., Sussmann, R., Stremme, W., and Rockmann, A.: The exploitation of ground-based Fourier transform infrared observations for the evaluation of tropospheric trends of greenhouse gases over Europe, Environ. Sci., 2, 283-293, 2005.

Dhomse, S., Weber, M., Wohltmann, I., Rex, M., and Burrows, J. P.: On the possible causes of recent increases in northern hemispheric total ozone from a statistical analysis of satellite data from 1979 to 2003, Atmos. Chem. Phys., 6, 1165-1180, 2006, http://www.atmos-chem-phys.net/6/1165/2006/.

Flaud, J. M., Wagner, G., Birk, M., Camy-Peyret, C., Claveau, C., De Backer-Barilly, M. R., Barbe, A., and Piccolo, C.: Ozone absorption around $10 \mu \mathrm{m}$, J. Geophys. Res., 108(D9), 4269, doi:10.1029/2002JD002755, 2003.

Gardiner, T., Forbes, A., de Mazière, M., Vigouroux, C., Mahieu, E., Demoulin, P., Velazco, V., Notholt, J., Blumenstock, T., Hase, F., Kramer, I., Sussmann, R., Stremme, W., Mellqvist, J., Strandberg, A., Ellingsen, K., and Gauss, M.: Trend analysis of greenhouse gases over Europe measured by a network of ground-based remote FTIR instruments, Atmos. Chem. Phys., 8, 6719-6727, 2008 ,

http://www.atmos-chem-phys.net/8/6719/2008/.

Hadjinicolaou, P., Pyle, J. A., and Harris, N. R. P.: The recent turnaround in stratospheric ozone over northern middle latitudes: A dynamical modeling perspective, Geophys. Res. Lett., 32, L12821, doi:10.1029/2005GL022476, 2005.

Hase, F., Blumenstock, T., and Paton-Walsh, C.: Analysis of the instrumental line shape of high-resolution Fourier transform IR spectrometers with gas cell measurements and new retrieval software, Appl. Opt., 38, 3417-3422, 1999.

Hase, F.: Inversion von Spurengasprofilen aus hochaufgelösten bodengebundenen FTIR-Messungen in Absorption. Wissenschaftliche Berichte Forschungszentrum Karlsruhe, FZKA 6512; ISSN 0947-8620, 2000.

Hase, F., Hannigan, J. W., Coffey, M. T., Goldman, A., Höpfner, M., Jones, N. B., Rinsland, C. P., and Wood, S. W.: Intercomparison of retrieval codes used for the analysis of high-resolution, ground-based FTIR measurements, J. Quant. Spectros. Radiat. Transfer, 87, 25-52, 2004.

IPPC (Intergovernmental Panel on Climate Change): Third Assessment Report: Climate Change 2001: The Scientific Basis, Chapter 4, Cambridge University Press, UK, 2001.

Isaksen I. S. A., Zerefos, C. S., Kourtidis, K., Meleti, C., Dalsøren, S. B., Sundet, J. K., Grini, A., Zanis, P., and Balis, D.: Tropospheric ozone changes at unpolluted and semipolluted regions induced by stratospheric ozone changes, J. Geophys. Res., 110, D02302, doi:10.1029/2004JD004618, 2005.

Jonson, J. E., Simpson, D., Fagerli, H., and Solberg, S.: Can we explain the trends in European ozone levels?, Atmos. Chem. Phys., 6, 51-66, 2006,

http://www.atmos-chem-phys.net/6/51/2006/. 
Kagawa, A., Kasai, Y., Jones, N. B., Yamamori, M., Seki, K., Murcray, F., Murayama, Y., Mizutani, K., and Itabe, T.: Characteristics and error estimations of stratospheric ozone and ozonerelated species over Poker Flat $\left(65^{\circ} \mathrm{N}, 147^{\circ} \mathrm{W}\right)$, Alaska observed by a ground-based FTIR spectrometer from 2001 to 2003, Atmos. Chem. Phys., 7, 3791-3810, 2007,

http://www.atmos-chem-phys.net/7/3791/2007/.

Kivi, R., Kyrö, E., Turunen, T., Harris, N. R. P., von der Gathen, P., Rex, M., Andersen, S. B., and Wohltmann, I.: Ozonesonde observations in the Arctic during 1989-2003: Ozone variability and trends in the lower stratosphere and free troposphere, J. Geophys. Res., 112, D08306, doi:10.1029/2006JD007271, 2007.

Logan, J. A.: Tropospheric Ozone: Seasonal behaviour, Trends, and Anthropogenic Influence, J. Geophys. Res., 90(D6), $10463-$ $10482,1985$.

Manney, G. L., Krüger, K., Sabutis, J. L., Sena, S. A., and Pawson, S.: The remarkable 2003-2004 winter and other recent warm winters in the Arctic stratosphere since the late 1990s, J. Geophys. Res., 110, D04107, doi:10.1029/2004JD005367, 2005.

Manney, G. L., Santee, M. L., Froidevaux, L., Hoppel, K., Livesey, N. J., and Waters, J. W.: EOS MLS observations of ozone loss in the 2004-2005 Arctic winter, Geophys. Res. Lett., 33, L04802, doi:10.1029/2005GL024494, 2006.

Miller, A. J., Cai, A., Tiao, G., Wuebbles, D. J., Flynn, L. E., Yang, S.-K., Weatherhead, E. C., Fioletov, V., Petropavlovskikh, I., Meng, X.-L., Guillas, S., Nagatani, R. M., and Reinsel, G. C.: Examination of ozonesonde data for trends and trend changes incorporating solar and Arctic oscillation signals, J. Geophys. Res., 111, D13305, doi:10.1029/2005JD006684, 2006.

Newchurch, M. J., Yang, E.-S. , Cunnold, D. M., Reinsel, G. C., Zawodny, J. M., and Russell III, J. M.: Evidence for slowdown in stratospheric ozone loss: First stage of ozone recovery, J. Geophys. Res., 108(D16), 4507, doi:10.1029/2003JD003471, 2003.

Oltmans, S. J., Lefohn, A. S., Harris, J. M., Galbally, I., Scheel, H. E., Bodeker, G., Brunke, E., Claude, H., Tarasick, D., Johnson, B. J., Simmonds, P., Shadwick, D., Anlauf, K., Hayden, K., Schmidlin, F., Fujimoto, T., Akagi, K., Meyer, C., Nichol, S., Davies, J., Redondas, A., and Cuevas, E.: Long-term changes in tropospheric ozone, Atmos. Environ., 40, 3156-3173, 2006.

Pougatchev, N. S., Connor, B. J., and Rinsland, C. P.: Infrared measurements of the ozone vertical distribution above Kitt Peak, J. Geophys. Res., 100, 16689-16697, 1995.

Randel, W. J., Wu, F., Vömel, H., Nedoluha, G. E., and Forster, P.: Decreases in stratospheric water vapor after 2001: Links to changes in the tropical tropopause and the Brewer-Dobson circulation, J. Geophys. Res., 111, D12312, doi:10.1029/2005JD006744, 2006.

Reinsel, G. C., Weatherhead, E. C. , Tiao, G. C., Miller, A. J., Nagatani, R. M., Wuebbles, D. J., and Flynn, L. E.: On detection of turnaround and recovery in trend for ozone, J. Geophys. Res., 107(D10), doi:10.1029/2001JD000500, 2002.

Reinsel, G. C., Miller, A. J., Weatherhead, E. C., Flynn, L. E., Nagatani, R. M., Tiao, G. C., and Wuebbles, D. J.: Trend analysis of total ozone data for turnaround and dynamical contributions, J. Geophys. Res., 110, D16306, doi:10.1029/2004JD004662, 2005.

Rinsland, C.P., Jones, N. B., Connor, B. J., Logan, Pougatchev, N. S., Goldman, A., Murcray, F. J., Stephen, T. M., Pine, A. S., Zander, R., Mahieu, E., and Demoulin, P.: Northern and Southern Hemisphere ground-based infrared spectroscopic measurements of tropospheric carbon monoxide and ethane, J. Geophys. Res., 103, 28 197-28 217, 1998.

Rodgers, C. D.: Inverse methods for atmospheric sounding: Theory and Practice, Series on Atmospheric, Oceanic and Planetary Physics, Vol. 2, World Scientific Publishing Co., Singapore, 2000.

Rodgers, C. D. and Connor, B. J.: Intercomparison of remote sounding instruments, J. Geophys. Res. 108, 4116-4129, 2003.

Rothman, L. S., Barbe, A., Benner, D. C., Brown, L. R., CamyPeyret, C., Carleer, M. R., Chance, K., Clerbaux, C., Dana, V., Devi, V. M., Fayt, A., Flaud, J.-M., Gamache, R. R., Goldman, A., Jacquemart, D., Jucks, K. W., Lafferty, W. J., Mandin, J.-Y., Massie, S. T., Nemtchinov, V., Newnham, D. A., Perrin, A., Rinsland, C. P., Schroeder, J., Smith, K. M., Smith, M. A. H., Tang, K., Toth, R. A., Vander Auwera, J., Varanasi, P., and Yoshino, K.: The HITRAN molecular spectroscopic database: Edition of 2000 including updates through 2001, J. Quant. Spectros. Radiat. Transfer, 82, 5-44, 2003.

Rothman, L. S., Jacquemart, D., Barbe, A., Benner, D. C., Birk, M., Brown, L. R., Carleer, M. R., Chackerian, C., Chance, K., Coudert, L. H., Dana, V., Devi, V. M., Flaud, J.-M., Gamache, R. R., Goldman, A., Hartmann, J. M., Jucks, K. W., Maki, A. G., Mandin, J. Y., Massie, S. T., Orphal, J., Perrin, A., Rinsland, C. P., Smith, M. A. H., Tennyson, J., Tolchenov, R. N., Toth, R. A., Vander Auwera, J., Varanasi, P., and Wagner, G.: The HITRAN 2004 molecular spectroscopic database, J. Quant. Spectros. Radiat. Transfer, 96, 139-204, 2005.

Schneider, M., Blumenstock, T., Hase, F., Höpfner, M., Cuevas, E., Redondas, A., and Sancho, J. M.: Ozone profiles and total column amounts derived at Izaña Tenerife Island, from FTIR solar absorption spectra, and its validation by an intercomparison to ECC-sonde and Brewer spectrometer measurements, J. Quant. Spectros. Radiat. Transfer, 245-274, 2005.

Schneider, M. and Hase, F.: Technical note: Recipe for monitoring of total ozone with a precision of around 1-DU applying midinfrared solar absorption spectra, Atmos. Chem. Phys., 8, 63-71, 2008 ,

http://www.atmos-chem-phys.net/8/63/2008/.

Schneider, M., Redondas, A., Hase, F., Guirado, C., Blumenstock, T., and Cuevas, E.: Comparison of ground-based Brewer and FTIR total column $\mathrm{O} 3$ monitoring techniques, Atmos. Chem. Phys., 8, 5535-5550, 2008,

http://www.atmos-chem-phys.net/8/5535/2008/.

Smit, H. G. J. and Straeter, W.: JOSIE-2000, Jülich Ozone Sonde Intercomparison Experiment 2000, The 2000 WMO international intercomparison of operating procedures for ECCozone sondes at the environmental simulation facility at Jülich, WMO Global Atmosphere Watch report series, No. 158 (Technical Document No. 1225), World Meteorological Organization, Geneva, 2004.

Solomon, S., Thompson, D. W. J. , Portmann, R. W., Oltmans, S. J., and Thompson, A. M.: On the distribution and variability of ozone in the tropical upper troposphere: Implications for tropical deep convection and chemical-dynamical coupling, Geophys. Res. Lett., 32, L23813, doi:10.1029/2005GL024323, 2005.

Steinbrecht, W., Claude, H., and Winkler, P.: Enhanced upper stratospheric ozone: Sign of recovery or solar cycle effect?, J. Geophys. Res., 109, D02308, doi:10.1029/2003JD004284, 2004a. 
Steinbrecht, W., Claude, H., and Winkler, P.: Reply to comment by D. M. Cunnold et al. on "Enhanced upper stratospheric ozone: Sign of recovery or solar cycle effect?", J. Geophys. Res., 109, D14306, doi:10.1029/2004JD004948, 2004b.

Steinbrecht, W., Claude, H., Schonenborn, F., McDermid, I. S., Leblanc, T., Godin, S., Song, T., Swart, D. P. J., Meijer, Y. J., Bodeker, G. E., Connor, B. J., Kampfer, N., Hocke, K., Calisesi, Y., Schneider, N., de la Noe, J., Parrish, A. D., Boyd, I. S., Brühl, C., Steil, B., Giorgetta, M. A., Manzini, E., Thomason, L. W., Zawodny, J. M., McCormick, M. P., Russell III, J. M., Bhartia, P. K., Stolarski, R. S., and Hollandsworth-Frith, S. M.: Long-term evolution of upper stratospheric ozone at selected stations of the Network for the Detection of Stratospheric Change (NDSC), J. Geophys. Res., 111, D10308, doi:10.1029/2005JD006454, 2006.

Stolarski, R. S. and Frith, S. M.: Search for evidence of trend slowdown in the long-term TOMS/SBUV total ozone data record: the importance of instrument drift uncertainty, Atmos. Chem. Phys., 6, 4057-4065, 2006, http://www.atmos-chem-phys.net/6/4057/2006/.

Tarasick, D. W., Fioletov, V. E., Wardle, D. I., Kerr, J.B., and Davies, J.: Changes in the vertical distribution of ozone over Canada from ozonesondes: 1980-2001, J. Geophys. Res., 110, D02304, doi:10.1029/2004JD004643, 2005.
Weatherhead, E. C. and Andersen, S. B.: The search for signs of recovery of the ozone layer, Nature, 441(7089), 39-45, doi:10.1038/nature04746, 2006.

WMO (World Meteorological Organization): Scientific Assessment of Ozone Depletion: 2002, Global Ozone Research and Monitoring Project-Report No. 47, Geneva, 2003.

WMO (World Meteorological Organization): Scientific Assessment of Ozone Depletion: Global Ozone Research and Monitoring Project-Report No. 50, Geneva, 2006.

Yang, E.-S., Cunnold, D. M., Salawitch, R. J., McCormick, M. P., Russell III, J., Zawodny, J. M., Oltmans, S., and Newchurch, M. J.: Attribution of recovery in lower-stratospheric ozone, J. Geophys. Res., 111, D17309, doi:10.1029/2005JD006371, 2006.

Zanis, P., Maillard, E., Staehelin, J., Zerefos, C., Kosmidis, E., Tourpali, K., and Wohltmann, I: On the turnaround of stratospheric ozone trends deduced from the reevaluated Umkehr record of Arosa, Switzerland, J. Geophys. Res., 111, D22307, doi:10.1029/2005JD006886, 2006.

Zbinden, R. M., Cammas, J.-P., Thouret, V., Nédélec, P., Karcher, F., and Simon, P.: Mid-latitude tropospheric ozone columns from the MOZAIC program: climatology and interannual variability, Atmos. Chem. Phys., 6, 1053-1073, 2006, http://www.atmos-chem-phys.net/6/1053/2006/. 